

\section{Summary findings}

What kind of privatization program is best suited to stimulate enterprise restructuring in former centrally planned economies? One view, expressed by most Western business and political leaders, is that privatization is best pursued case by case, with emphasis on sales to new owners, including foreign investors.

Another view, espoused by a minority of "radical" economists and economists-turned-politician, was that restructuring is hest pursued through economic incentives, combined with "mass" privatization of state enterprises so that they become widely held (public) joint stock corporations.

The ultimate test, of course, is future productivity growth and rising welfare standards. We cannot yet measure these. The disaggregated data on production and employment by industry required for such a measure either are not available or are unreliable.

The only objective measure available - comparable across countries - is export performance. Trade data reveal to what extent firms have been able to reorient themselves to create and exploit competitive advantages. We now have four years of data, enough to get an idea of what is going on, and to compare one Central or Eastern European country's performance against another's.

The data suggest that the Crech Republic, the country that has pursued mass privatization most actively and credibly, has also done best in restructuring its industries and reorienting them toward world markets. Those that pursued a gradualist approach - Hungary being the main example - have changed their export structure less, but export growth has also been above average.

This paper - a product of the Finance and Private Sector Development Division, Europe and Central Asia, and Middle East and North Africa Regions, Technical Department - is part of a larger effort in the region to analyze progress and policy options in transition econnmies. Copies of this paper are available frec from the World Bank, $1818 \mathrm{H}$ Street NW, Washington, DC 20433. Please contact Ms. Faten Hatab, room H8-087, extension 35835 (25 pages). March 1995.

The Policy Reseanch Working Paper Series disseminates the findings of work in progress to encourage the exchange of ideas abount development issues Ar objective of the series is to get the findings out quickly, even if the presentations are less than fully polished. The papers cany the names of the authors and should be used and cited accordingly. The findings, interpretations, and conclusions are the authors' oum and should not be attributed to the World Bank, its Executive Board of Directors, or any of its member courtries. 


\title{
Enterprise Restructuring in Eastern Europe How Much? How Fast? Where? Preliminary Evidence from Trade Data
}

\author{
Bernard Hoekman and Gerhard Pohl
}

The World Bank

We are very grateful to Ying Lin for his excellent research assistance in compiling the database used in this paper; to Alexander Italianer, Jerzy Rozanski, Zhen Kun Wang and Alan Winters for their help in obtaining and understanding the raw data; to Faten Hatab for report processing and preparation; and to Roland Eggerer and participants in a World Bank seminar for helpful comments. 


\section{Introduction}

What kind of privatization program is best suited to stimulate enterprise restructuring of formerly centrally planned economies? This question has been hotly debated since 1989 . Two opposing views have been most prominent. The first view, expressed by most Western business and political leaders is that privatization is best pursued case-by-case, with emphasis on sales to new owners including foreign investors. The second view, espoused by a minority of 'radical' economists and economists-turnedpoliticians was that restructuring is best pursued through economic incentives, combined with "mass" privatization of State enterprises to become widely held ('public') joint stock corporations. Hungary, for example, has followed the graciual, case-by-case approach; the Cztch Republic and Russia have relied on mass privatization. In Poland, mass privatization has been held up for nearly four years.

The ultimate test, of course, is future productivity growth and rising welfare standards. We cannot yet measure these. The disaggregated data on production and employment by industry required to do this are either not available or unreliable. ${ }^{1}$ The only objective measure available, comparable across countries, is export performance. Detailed export statistics provide not only an indirect measure of structural change, but export performance has a very direct impact on productivity, since higher exports will permit higher imports of scarce Western capital goods and services (computers, machinery, process controls, telecommunication equipment, software, management consulting, etc.). In the near term, productivity growth will crucially depend on such imported items.

Trade data reveal to what extent firms have been able to reorient themselves to create and exploit competitive advantages. We now have four years of data, enough to get an idea of what is going on, and to compare the performance of the Central and East European Economics (CEECs) to one another.
The data suggest that the country that pursued mass privatization the most actively and credibly--the Czech Republic--has done the best in terms of restructuring its industries and reorienting them towards world markets. Those that pursued a gradualist approach--Hungary being the main example-have unuergone less change in the structure of exports. However, export growth has also been above-average. The two countries where the output collapse has been most severi-Bulgaria and Romania-have the weakest overall trade performance. Buigaria differs from Romania, however, in that the composition of its exports to the EU changed very rapidly, suggesting that substantial restructuring is occurring.

Shifts in the structure, composition and geographic pattern of trade flows alone are, of course, not necessarily indicative of restructuring at the levil of the firm. Firms could have reoriented exports from Eastern to Western countries without altering any of the characteristics of the gouts involved, and therefore without restructuring. However, CMEA and Western markets were to a large extent segmented, with different quality standards and designs. Except for raw materials, the shift towards Western markets is not possible without considerable 'restructuring' by adopting new product design, technologies, quality control, marketing strategies, and so forth. Restructuring may or may not involve visible actions such as plant closures and layoffs.

Aggregate unemployment may not embody much information on the magnitude of restructuring that is occurring in an economy. It has sometimes been argued that the Czech Republic's unemployment rate of only 3.5 percent indicates that much of the required restructuring is yet to come, especially as rates vary between 10 and 16 percent in the other CEECs. The export performance of the Czech Republic is at odds with this view. ${ }^{2}$

The impact of the European Union's (EU) trade policy vis-a-vis the CEECs has been just as hotly debated as privatization. ${ }^{3}$ Results to date suggest that exports have not been 


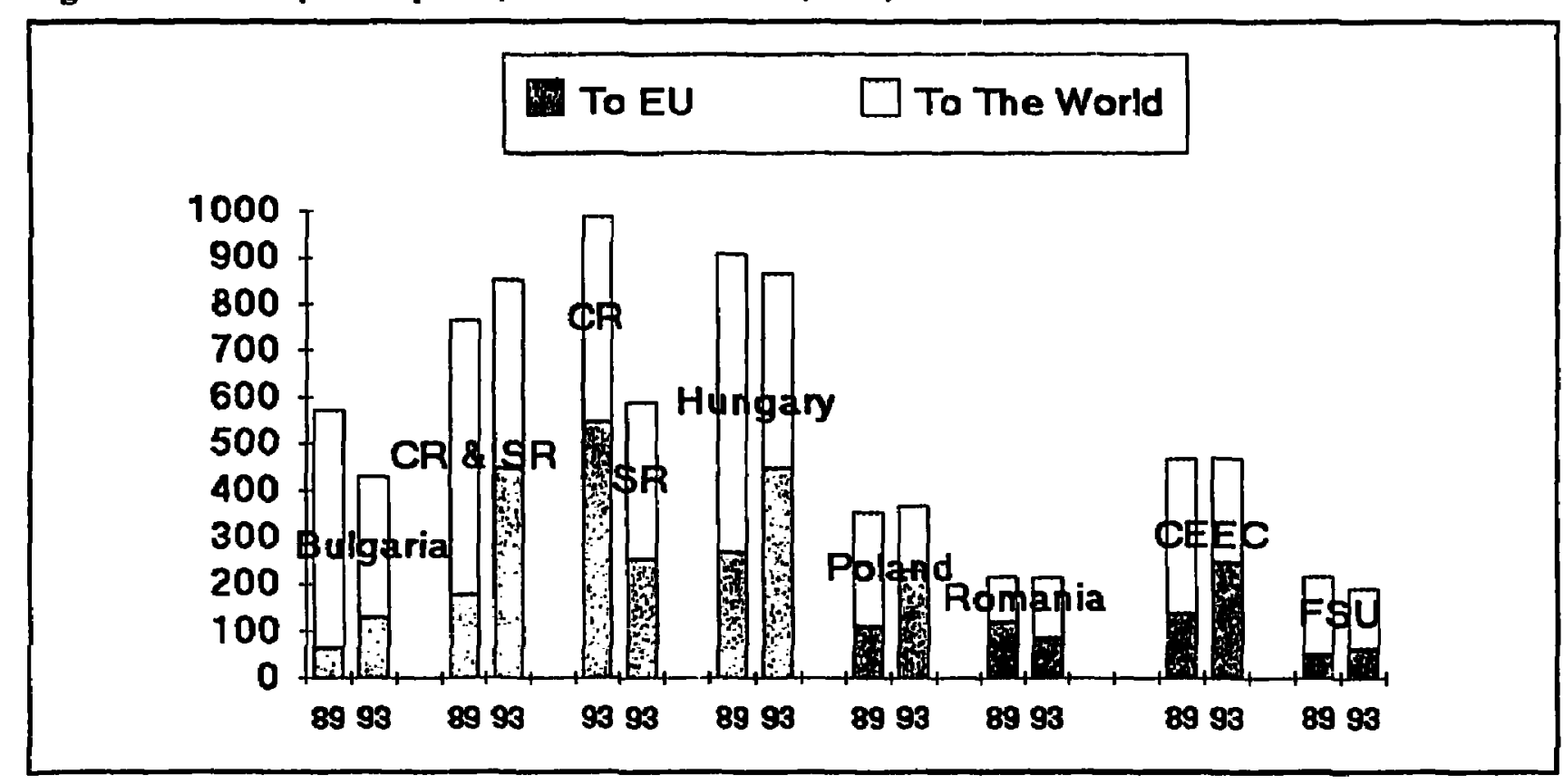

constrained by restricted market access for 'sensitive' products. Rapid growth in exports occurred in both sensitive and non-sensitive items. Indeed, export growth in certain sensitive products-agriculture foremost-has been far below potential (market access granted), suggesting that the CEECs may not have as strong a comparative advantage in agriculture as is often believed.

\section{Measures of Change: Aggregate Trade Indicators}

What follows presents and discusses a number of summary measures that have been compiled on the basis of import data reported by the European Communities. Data on the imports from the CEECs are used rather than reported exports by each of the CEECs. We also mostly abstract from exports to the rest of the world. Although this reflects data availability, an analysis that is limited to the EU is of interest given the fact that the CEECs are clearly 'specializing' in the EU market. The EU now accounts for over 50 percent of the CEECs' exports (Table 1).
The various measures that are discussed in what follows are indirect indicators of the restructuring underway. What matters is not the absolute value of any indicator, but how the Eastern European countries compare to each other. Such comparisons provide some information on the impact of the different strategies with regard to 'restructuring' policies: privatization, trade liberalization, etc. Macroeconomic factors will of course be important as well, but mainly affect aggregate performance, not changes in the structure and composition of exports. It is the latter that is the focus of attention here.

Table 1: Share of EU in total exports.

\begin{tabular}{|lcc|}
\hline & 1989 & 1993 \\
CEECs & 29.3 & 52.3 \\
FSU & 23.5 & 32.4 \\
\hline
\end{tabular}

It is useful to start with a brief discussion of total exports of the CEECs and the FSU in the last 5 years. Figure 1 reports per capita exports of the CEECs, to the world and to the EU. Two points stand out. First, the decline in the value of total external trade after 
1989, due to the demise of the CMEA was offset by 1993 for the majority of the CEECs. ${ }^{3}$ Per capita exports from the CEECs to the EU nearly doubled. The growth rate of per capita exports to the EU is the highest for the Czech and Slovak Republics, ${ }^{6}$ at 26 percent per year on average, followed by Bulgaria and Poland at 20 percent, and Hungary with 14 percent. The absolute value of per capita exports to the world is highest for the Czech Republic at $\$ 1,000$ followed by Hungary at around $\$ 850$ in 1993. Second, a marked shift in exports towards the EU occurs. Of the comparator countries, only China achieved similar performance. ${ }^{7}$ The Czech and Slovak Republics also demonstrate one of the largest shifts in the geographic pattern of exports, by 30 percentage points. ${ }^{8}$

The CEECs' trade structure has changed substantially in the last four years. Total exports to the EU rose by 14 per cent per year on average between 1989 and 1993 (from ECU 12 billion in 1989 to 20 billion in 1993). In this period, total EU imports rose by only 2.1 per cent per year, while world trade increased by 3.7 per cent per year. The CEECs therefore substantially increased their market share in the EU (Table 2).

Table 2: Market share in the EU $(\%)$

\begin{tabular}{|lll|}
\hline & 1989 & 1993 \\
CEECs & 2.7 & 4.1 \\
FSU & 3.0 & 3.2 \\
Bulgaria & 0.12 & 0.19 \\
CSFR & 0.56 & 1.23 \\
Hungary & 0.58 & 0.81 \\
Poland & 0.85 & 1.54 \\
Romania & 0.57 & 0.34 \\
\hline
\end{tabular}

For the six countries that have signed Association Agreements-Bulgaria, the Czech Republic, Hungary, Poland, Romania and the Slovak Republic-total import penetration rose from 2.7 per cest in 1989 to 4.1 per cent in 1993. Individual co:intry market share growth was often substantially higher with both Poland and the Czech and Slovak Republics doubling their share of the EU market, and Bulgaria almost doing so.

Table 3: Average annual growth in exports to EU

\begin{tabular}{|lc|}
\hline & $1989-93(\%)$ \\
Bulgaria & 16 \\
CSFR & 24 \\
Hungary & 11 \\
Poland & 18 \\
Romania & -10 \\
& \\
FSU & 4 \\
\hline
\end{tabular}

The Czech and Slovak Republics are the 'star' performer on the basis of growth in exports to the EU (Table 3). In 1989 reported imports by the EU from the Czech and Slovak Republics, Hungary and Romania were roughly equal at ECU 2.5 billion. By 1993, exports from the Czech and Slovak Republics had attained ECU 6 billion, Hungarian exports were slightly below ECU 4 billion, and those of Romania had fallen to ECU 1.7 billion (Figure 2). Exports of the Czech and Slovak Republics grew by 24 percent per year on average during the $1989-93$ period, outperforming China. Poland and Bulgaria follow second and third in terms of export grcwth.

Table 4: Actual and 'long run' predicted exports to EU (ECU billion)

\begin{tabular}{|lrr|}
\hline & 1993 & Predicted \\
Bulgaria & 0.9 & 3.9 \\
CSFR & 6.0 & 12.5 \\
Hungary & 3.9 & 4.5 \\
Poland & 7.5 & 8.5 \\
Romania & 1.7 & 3.0 \\
FSU & 15.5 & 31.2 \\
\hline
\end{tabular}

How significant are these changes in trade patterns? Spatial trade patterns are usually 


\section{Figure 2": Exports to'Eu, $1989-93$}

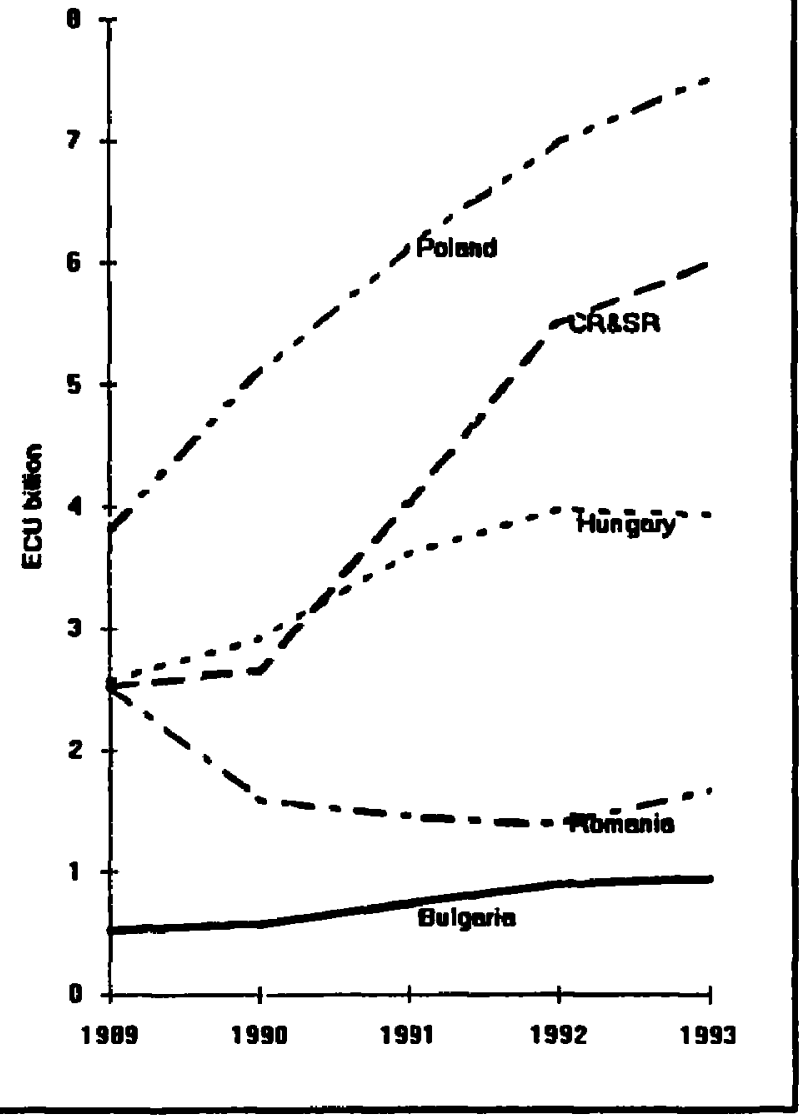

well explained by 'gravity' models where trade between partner countries is determined by the GDPs of the two partners, their populations, and the geographic distance between them. They can be used as one benchmark against which the trade performance of the CEECs can be compared. If the actual value of exports in 1993 are compared with a gravity model-based 'prediction' of longer-run 'potential' exports (Baldwin, 1994), the CEECs have already moved substantially towards realizing their potential (Table 4).

The same conclusions emerge if actual EU market shares and export-to-GDP ratios are compared with gravity model predictions (Appendix Table 1). The 'openness' of CEEC economies as indicated by their export-to-GDP ratios varies from 16 percent for Poland to 35 percent for Bulgaria (Figure 3). Although these ratios will be influenced by valuation effects that affect GDP calculations (e.g., exchange rate levels), they are nonetheless suggestive. The Czech and Slovak Republics and Bulgaria appear to be the most 'open', significantly more so than the other CEECs. This in turn has implications for the potential of these countries to absorb imports of investment goods which, in turn, will strengthen the restructuring process. A comparison with the long-run openness ratios predicted by a gravity model (Hamilton and Winters, 1992) suggests that the CEECs appear to have come close to attaining the future (Figure 3). The main exception is Hungary, in part due to its (less undervalued?) exchange rate.

Figure 3: Actual and 'predicted' openness ratios (exports/GDP)

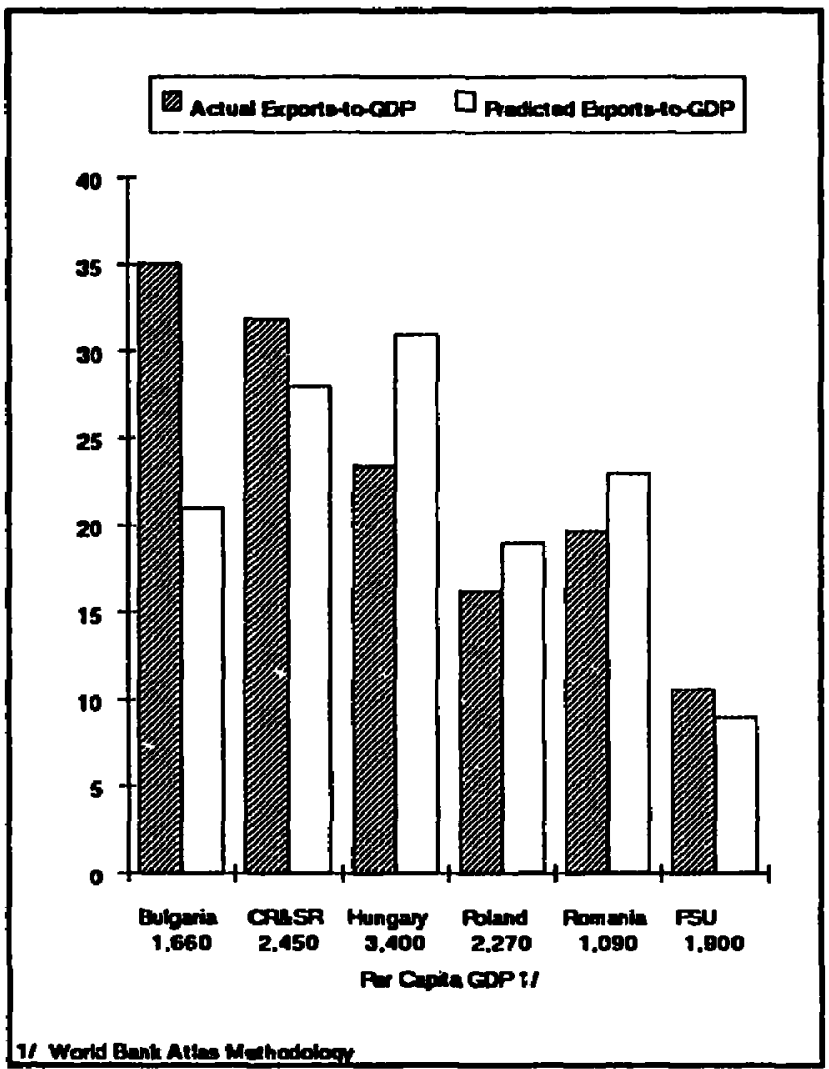

Trade performance of the last 4 years suggests that the long run will be achieved much more rapidly than most observers expected in 1989, and the composition of exports substantially different than what was predicted. 
For example, Aghion et al. (1992) concluded that elimination of barriers to imports by the EU would increase exports of Czechoslovakia, Hungary and Poland by 40 percent. In the event, exports increased by 95 percent during 1989-93. Agricultural exports were expected to expand by 75 percent; they actually fell slightly. Mastropasqua and Rolli (1994), using the SMART partial equilibrium simulation model, predicted that EU liberalization would increase 'traditional' exports in goods with export values above $\$ 3$ million (at the 8-digit level) in 1988 by $\$ 245$ million, $\$ 175$ million and $\$ 115$ million, for Poland, the Czech and Slovak Republics, and Hungary, respectively. In fact, exports of such goods increased by $\$ 850$ million for Poland and $\$ 215$ million for the Czech and Slovak Republics, and declined by $\$ 220$ million for Hungary.9 As discussed at greater length below, the importance of 'traditional' exports had fallen dramatically by 1993.

\section{Disaggregated Measures of Change in Export Composition}

Restructuring occurs at the level of the firm. The trade data that have been discussed so far are highly aggregated and only suggestive regarding the magnitude of the changes that have been occurring at the firm/industry level. Although trade statistics are not reported at the level of the firm, detailed statistics are available, for about 10,000 product categories imported by the EU. These data provide a valuable source of information on the changes in production for export in the CEECs and the FSU.

A useful indicator of the change in the structure of exports is the sum of the absolute changes in the value of exports of individual commodities between 1989 and 1993, divided by the 1989 value. This measure is reported in Appendix Table 2. It treats increases and decreases symmetrically, and is intended to give an impression of 'how much' change occurred in exports. For ease of comparison, the figures are
Figure 4: Structural change in exports relative to sample moan. $1989-93$

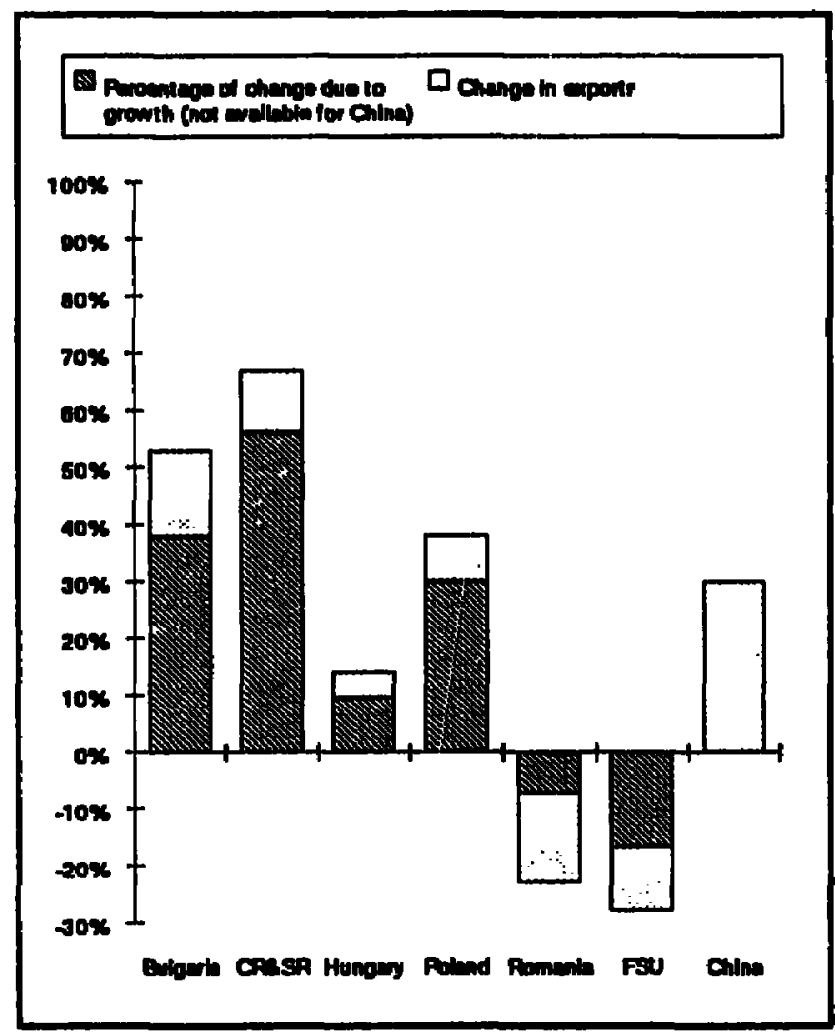

expressed as a function of the mean change in trade structure for the sample of selected countries. ${ }^{10}$ As can be seen in Figure 4, the structural changes in exports are much higher for the CEECs than for other countries. This suggests substantial restructuring is occurring. The absolute value of the change between 1989 and 1993 is particularly high for the Czech and Slovak Republics." The relatively high number for Bulgaria reflects in part the small initial value of trade with the EU.

As mentioned earlier, the change indicator gives equal weight to positive and negative changes. Both are equally relevant as far as restructuring is concemed. Figure 4 also shows that the Czech and Slovak Republics have very few declining export sectors: over $\mathbf{8 0}$ percent of the change reflects commodities where export growth occurs. Romania lies at 
the other end of the scale: only 30 percent of the change is due to growing exports.

If restructuring is occurring one would expect to observe that some products cease to be exported while other 'new' products come on stream. Figure 5 shows that the CEECs greatly expanded the number of 8-digit tariff line items exported to the EU during 1989-93. The Czech and Slovak Republics stand out in particular in this regard, increasing the number of lines exported from 41.6 percent of all the goods imported by the EU in 1989 to 61.5 percent in 1993. All the CEECs have rapidly diversified their exports to the EU. Comparator countries have managed to diversify into new products only at a much slower pace. With the exception of China, the number of iterns exported to the EU by comparators such as Israel or Turkey is now significantly less than the Czech Republic, Hungary and Poland.

\section{Figure 6: Number of commodities exported} to EU, 1989 and 1993

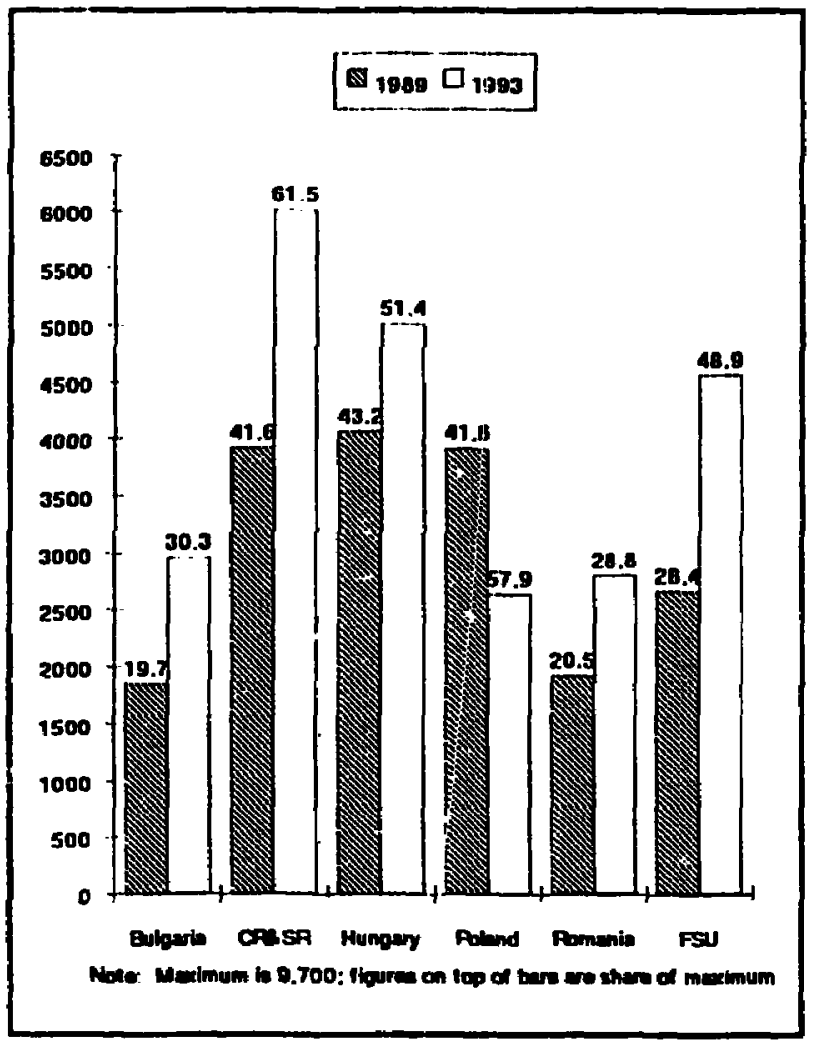

Figure 5: Relative importance of 'explred' and new products (percent)

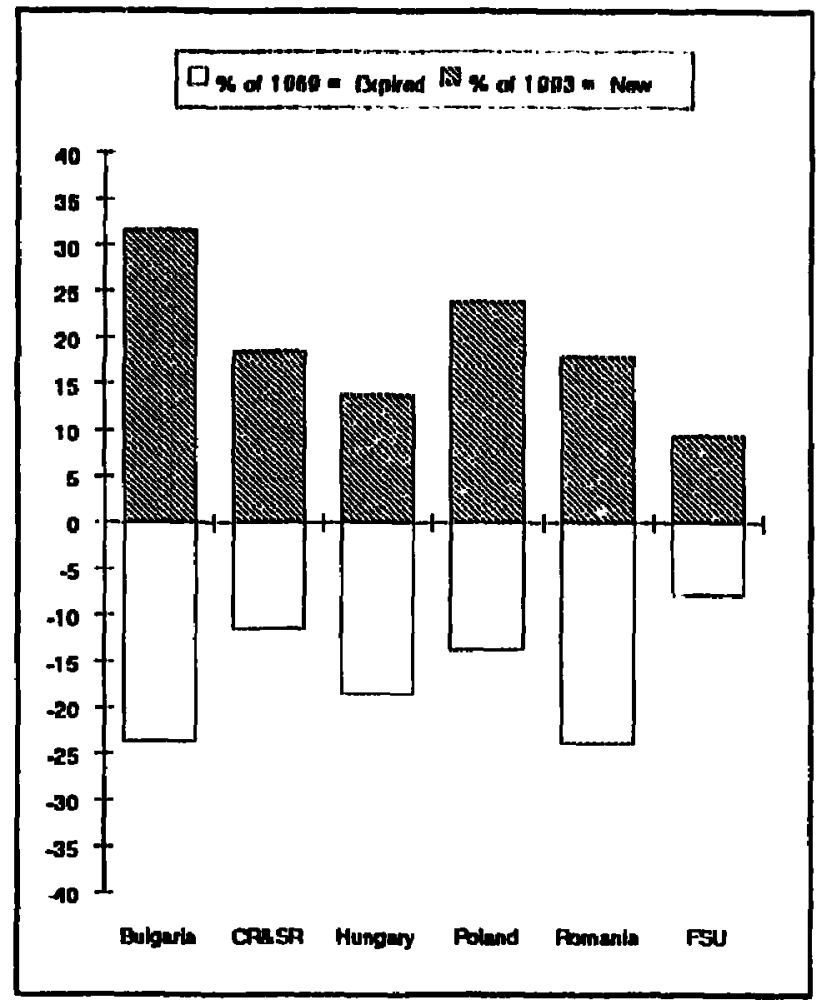

How large are the exports of the 'new' commodities relative to total exports? The value of exports of new and 'expired' tariff lines relative to total exports provides some information in this regard. ${ }^{12}$ New items constitute a significant share of total exports in each year of the 1989-93 period (Appendix Table 3). Figure 6 provides a summary view of the relative importance of 'expired' and 'new' products in total exports. Two measures are reported: (i) the share of products that ceased to be exported between 1989 and 1993, expressed as a percentage of 1989 total exports to the EU; and (ii) the share of 1993 total exports to the EU that comprise products that were not exported at all in 1989.

The value of commodities that cease to be exported tends to be smaller than the value of new products that come on stream. New products account for between 10 and 30 percent of total exports in 1993 for the CEECs. Expired products tend to represent the equivalent of 10 - 
20 percent of total exports in 1989. They exceed by a substantial margin the changes in exports by comparator countries such as China or Turkey. Of the CEECs, Bulgaria is the most 'dynamic'. Over the four year period, the equivalent of almost one-quarter of 1989 exports by value 'disappears', while about one-third of 1993 exports are 'new' in the sense that products are involved that were not exported in 1989. The numbers for the other CEECs are somewhat lower, but still high.

Another way of getting a sense of the changes that have taken place is to look at the performance of 'traditional' or 'established' exports since 1989. As noted earlier, commodities that were important export items in 1989 have become much less significant (see Table 5). By contrast, 8-digit product categories that accounted for less than ECU 3 million in 1989 grew extremely fast in all the CEECs. Average annual growth rates for this category were $\mathbf{4 3}$ percent for the Czech and Slovak Republics; 40 percent for Poland; and 55 percent in the FSU (Appendix Table 4). The share of this group of goods in total exports consequently increased sharply. For the Czech and Slovak Republics such 'non-traditional' exports accounted for $\mathbf{7 0}$ percent of total exports in 1993, as compared to only 30 percent in 1989. For Bulgaria, the figures are $\mathbf{8 0}$ and $\mathbf{2 0}$ percent, respectively. This illustrates the importance of decentralized production and trade decision resulting from privatization and price liberalization.

The change in specialization of the CEECs in their exports to the EU that occurred over the 1989-93 period is an additional source of information. ${ }^{13}$ Specialization indices for broad categories of exports to the EU in 1989 and 1993 are reported in Appendix Table 5. The CEECs tend to be specialized in leather products and footwear, garments, ferrous and nonferrous metais, and furniture. Bulgaria, Hungary and Poland are also specialized in agriculture, although their relative specialization in this sector has been declining. Bulgaria in
Tabl. 5: Share of 'traditional' products $1 /$ in total exports, 1989-93 (parcent)

\begin{tabular}{|l|r|r|r|}
\hline & $\begin{array}{c}\text { Share in } \\
1989\end{array}$ & $\begin{array}{c}\text { Share in } \\
1993\end{array}$ & $\begin{array}{r}\text { Annual } \\
\text { Average } \\
\text { Change } \\
\text { in Value }\end{array}$ \\
\hline Bulgaria & 44 & 19 & -5.6 \\
CSFR & 60 & 30 & 4.1 \\
Hungary & 59 & 35 & -2.1 \\
Poinnd & 74 & 50 & 7.2 \\
Romania & 80 & 51 & -19.4 \\
FSU & 96 & 80 & -0.8 \\
\hline
\end{tabular}

y Greater than ECU $3 \mathrm{mln}$ in 1989

particular shows very large shifts towards leather/footwear; fibers; raw materials/cement; and nonferrous metals, and away from steel and armaments. ${ }^{14}$ Romania also reveals large changes: towards leather/footwear and garments, and away from mineral resources andnonferrous metals. The Czech and Slovak Republic demonstrate a sharp shift away from agriculture, wood products and arms, and towards nonferrous metals, transport equipment and machinery. Poland becomes specialized in wood products and transport equipment, and less specialized in agriculture. Hungary shows the least change of the CEECs, in part due to its longer exposure to world market prices.

The expansion of the number of new products and the absolute number of tariff lines exported to the EU suggests that much of the trade that is occurring between the EU and the CEECs is intra-industry trade, that is, the same types of goods are shipped both ways. Intraindustry trade has been expanding very rapidly between the CEECs and the EU. Intra-industry trade intensity indices for the Czech and Slovak Republics and Hungary now exceed the value of intra-industry trade for countries such as South Korea or Israel, and are approaching levels registered by the U.S. or the EFTA countries in their trade with the EU. ${ }^{\text {is }}$ Intra-industry trade is currently at about the level it was for trade between North and South Europe in the aarly 
1980s (when it varied between 0.4 and 0.6 , see Neven, 1990). Much of the East-West intriindustry trade is with Germany and the EU's Southern members (Neven, 1994).

The rapid increase in intra-industry trade has implications for adjustment costs and market access opportunities in the furure. Adjustment costs abroad are likely to be lower in an intraindustry trade context because jobs lost due to import penetration may be offset by jobenhancing expansion in demand for imports from the foreign partner for similar goods. The political opposition to liberalizing and expanding intra-industry trade is generally much more muted than in instances where trade flows are predominantly of the inter-industry type. ${ }^{16}$

Intra-industry trade can also be a mechanism through which transfers of technology occur. The Europe Agreements with the CEECs have increased the incentives for EU sumpliers/retailers to engage in so-called outward processing trade, where raw material or components are exported for assenubly in lower wage countries and then re-imported. Outward processing has been used intensively for sectors such as garments, electrical machinery and furniture. Importers provide designs, insist on quality control, take care $r_{1}^{e}$ marketing, etc. This is a good way for firms in partner countries to reduce the costs and risks associated with development of export markers, while at the same time obtaining know-how from suppliers. Outward processing trade can be seen as a form of non-equity foreign direct investment.

Export under outward processing arrangements accounted for about 18 percent of total CEEC exports to the EU in 1993, up from 10 percent in 1989 (Table 6). Most of the processing occurs in leather/footwear, clothing, electrical machinery, precisic 1 instruments and furniture. All of these activities are labor intensive. ${ }^{17}$

Outward processing trade may be driven by a variety of forces. It may be used as a way
Table 6: Share of 'subcontracting' in total exports of the EU $(\%)$

\begin{tabular}{|lrr|}
\hline & 1989 & 1993 \\
\hline Bulghriu & 4.4 & 13.7 \\
CSIFR & 5.1 & 12.6 \\
Hungary & 16.4 & 20.2 \\
Poland & 9.1 & 18.6 \\
Romania & 12.9 & 30.1 \\
CEEC & 10.4 & 17.9 \\
FSU & 0.8 & 1.9 \\
\hline
\end{tabular}

to obtain market access, as trade policy in the EU tends to be less restrictive for processed goods reflecting a perception that it allows high cost industries located in the $\mathrm{IU}$ to subcontract labor-intensive parts of their production process to third countries, thereby allowing them to remain in business. Duties on goods that are reimported after processing are usually based on the value added abroad, not on the gross value of the goods. The Europe Agreements eliminated tariffs on such trade (Naujoks and Schmidt, 1994). However, it may also reflect imperfections in the policy and/or regulatory environment in the processing country. Subcontracting can allow foreign partners to trade with local firms without having to establish production facilities. Of course, this is only the case insofar as technologies are not such that control through equity investment (FDI) is required. The reach of such subcontracting is therefore limited to relatively 'low-tech' activities. Subcontracting can nonetheless do much to employ local factors of production and transfer general foreign knuw-how and management practices.

\section{Expanding and Declining Products}

The combination of expansion in the 'product line' exported to the EU and the decline in the relative importance of 'traditional' exports has led to the establishment of a more diversified export base in the CEECs. This Section 
provides a flavor of the dynamism demonstrated by entreprencurs in the CEECs and the FSU by focusing on some of the fastest growing and declining products in their cxport trade. The response to the changes in the incentive structure resulting from price liberalization, privatization and gruater access to the EU markets has been nothing less than impressive.

\section{What are the growth areas?}

Clothing, footwear, and machinery dominate in all the CEECs. Exports of these products grew very fast in the 1989-93 period. Box 1 provides a listing of the top ten 'new' products-defined as being zero or very close to it in 1989-exported to the EU in 1993, sorted by absolute increase.

Bulgaria

For Bulgaria, clothing and footwear accounted for a quarter of all exports to the EU, up from less than 10 percent in 1989 . The second major growth area for Bulgaria are silver and copper which increased from virtually zero percent to 9 percent of total exports. Products where exports are both substantial and grew by over 100 percent per year include cathodes, disodium carbonate, frozen fatty goose and duck, conveyors and transmission belts, ceramic tiles, and bovine leather.

\section{Czech and Siovak Republics}

Exports of machinery and vehicles dominate export growth in the Czech and Slovak Republics. The largest category in terms of absolute growth was motor vehicles, followed by automotive components, fixed electrical capacitors, motor vehicle parts ${ }^{18}$ and footwear. Growth rates of many products are frequently triple digit, and sometimes approach quadruple digits.

Products for which exports grew by more than 100 percent (from already substantial base $)^{19}$ per year during $1989-93$ include: portland cement, prefabrlcated bulldings, metal furniture, ammonium nitrate, ceramic bullding bricks, typewriters, DC motors, compact dises, upholstered scats and parts thereof, electronic components, tantallum, footwear, clectric energy, sea-golng vessels, live cows, doois and windows, reservoirs, builders joinery, raw hides, sewing machines, and articles of plastic. The ave - ge annual growth rate of exports of these products was over 150 pereent, an impressive performance by any standard ${ }^{20}$

\section{Hungary}

Hungary's dynamic exports to the EU are similar to those of the Czech and Slovak Republics. Machinery and textiles and clothing are the most important exports. Hungary differs from the Czech and Slovak Republics in that a number of agricultural exports (sunflower seeds and sausages), organic chemicals, and wood products are products that have grown rapidly. As can be seen from Box 1, agricultural products figure prominently in Hungary's top 'new' exports.

Hungary's overall trade performance has been weaker than that of the Czech and Slovak Republics. As noted earlier, aggregate exports to the EU grew by 'only' 11 percent per year on average during 1989-93, as compared to 24 percent for the Czech and Slovak Republics. The number of dynamic 8-digit level product categories is consequently lower than for most other CEECs.

\section{Poland}

Clothing exports grew the most, accounting for 17 percent of total exports in 1993, up from 9 percent in 1989, followed by furniture and wood products exports 12 percent. The relative importance of transportation equipment (cars, ships, aircraft) doubled to 10 percent of total exports.

At the 8-digit level, motor cars, portland cement and upholstered seats are the mostrapidly 


\section{Box 1}

\begin{tabular}{|c|c|c|c|c|c|}
\hline \multicolumn{6}{|c|}{ Top 10 'New' Export Products by Country (8-diali leve) and Value in 1993 (ECU million) } \\
\hline \multirow[t]{10}{*}{ Bulgaria } & Unrefined copper & 22.2 & Poland & Sea going vessels & 124.3 \\
\hline & Unwrought silver & 18.2 & & Civil aircraft & 53.8 \\
\hline & Uppers of leather & 16.9 & & Frozen fillets of fish & 52.0 \\
\hline & Women's footwear & 9.8 & & Article of iron and stcel & 31.2 \\
\hline & Wire of refined copper & 9.6 & & Discharge lamps & 25.6 \\
\hline & Special spirits & 6.9 & & Live domestic cows & 23.2 \\
\hline & Fatty livers of duck & 5.8 & & Women trousers & 19.6 \\
\hline & Transmission belts & 4.6 & & Meat and edible offal & 18.8 \\
\hline & Turbo jets & 4.0 & & Lignite (unagglomerated) & 18.7 \\
\hline & Gas oils & 3.8 & & Mens footwear with sole & 17.8 \\
\hline \multirow[t]{10}{*}{ CSFR } & Fixed electrical capacitators & 33.9 & Romania & Mens footwear with sole & 17.6 \\
\hline & Unwrought tantalum & 31.5 & & Ash and residues & 11.7 \\
\hline & Uppers of leather & 30.1 & & Single phase AC motors & 10.3 \\
\hline & Parts/accessories of motors & 26.7 & & Sea-going tankers & 9.7 \\
\hline & Motor cars & 24.8 & & Women trousers & 8.5 \\
\hline & Articles of iron and steel & 24.4 & & Meat and offal of cows & 7.3 \\
\hline & Mixtures of ammonium nitrale & 24.1 & & Fuel oil from bitumen & 6.5 \\
\hline & Machinery and appliances & 22.8 & & Mens footwear with sole & 6.4 \\
\hline & Mens footwear with outer sole & 19.5 & & Ignition wiring sets & 4.7 \\
\hline & Electrical energy & 19.2 & & Flat rolled products & 4.5 \\
\hline \multirow[t]{11}{*}{ Hungary } & Reciprocating piston engines & 45.1 & & & \\
\hline & Mens footwear with outer sole & 28.2 & & & \\
\hline & Fatty livers of domestic geese & 27.5 & & & \\
\hline & Lambs, less than one year old & 27.2 & & & \\
\hline & Meat and edible meat offal & 26.2 & & & \\
\hline & Parts of electrical machinery & 25.3 & & & \\
\hline & Reciprocating piston engines & 25.2 & & & \\
\hline & Women footwear with sole & 18.8 & & & \\
\hline & Articles of iron and steel & 15.0 & & & \\
\hline & Parts of motor vehicles & 14.9 & & & \\
\hline & Live domestic cows & 14.3 & & & \\
\hline
\end{tabular}


expanding exports. Items with triple digit growth rates (and more than ECU 10 million in 1993) include sea-going vessels, civil aircraft, cathode ray tubes, gravel, cement clinker, certain chcmicals, leather, ignition wiring sets, copper wires, rails, ferro-chromium, cooking appliances, removable insoles, reservoirs, zinc, french windows, beech wood, paper, and builders joinery.

\section{Romania}

Romania's exports fell substantially over the $1989-93$ period, largely reflecting the collapse of exports of mineral fuels, aluminum, furniture and wood products, and iron and steel.

Significant growth occurred in exports of clothing and footwear. Their share in total exports to the EU rose from 16 to 45 percent in 1993. There are few significant and rapidly growing 8-digit items besides clothing and footwear.

FSU

Must of the growth in exports from the FSU are natural resources or natural resourcebased products. Copper and silver are two major exports with growth rates exceeding 100 percent per year on average. Other dynamic products are flat-rolled steel products, sunflower seeds, bovine leather, ammonium nitrate, waste and scrap of nickel and stainless steel, and collectors pieces (art works). There are few clothing or machinery products in the most dynamic 8-digit items. However, more recently manufactured exports have been expanding similarly rapidly as in Central Europe. As shown in Table 7, non-oil exports by Russia to the EU more than doubled between 1992 and 1993, the year after price liberalization. Footwear and clothing exports have been growing very fast-often at triple digits--rising from ECU 9 million in 1989 to ECU 295 million in 1993, with most of the growth after 1992.
Table 7: Russia coming on stream (ECU bn)

\begin{tabular}{|rrr|}
\hline & 1992 & 1993 \\
Non-oil exports & 2.6 & 5.4 \\
\hline
\end{tabular}

\section{Declining products}

The summary measures of thange in exports discussed earlier embody 'sunset' as well as 'sunrise' industries. Identification of the declining products in exports to the EU also provides information on the extent of restructuring in the CEECs and the FSU. The hardening of budget constraints and privatization programs should result in large declines in exports of those goods that used to be either heavily subsidized and/or were revealed to be nonprofitable. There is quite some diversity across the CEECs in this regard. The discussion that follows uses more aggregated data (2-digit) than the foregoing Section.

The CEECs can be separated into two groups: those with a large number of product categories where exports to the EU decline; and those with only a small number of declining products. Bulgaria, Hungary and RJmania are in the first group, the Czech and Slovak Republics and Poland in the second. The FSU is somewhere in between. Agricultural products and foodstuffs figure prominently in the declining export categories for the Czech and Slovak Republics, Hungary and Poland.

\section{Bulgaria}

One third of product groups exported to the EU had negative growth rates, of which twothirds fell by 10 percent per year or more. The largest absolute decline occurred for iron and steel exports. In contrast to the other CEECs (see below), agriculture plays a relatively minor role in the declining product groups. Items where large declines occurred include soaps, wickerw $: k$, wadding and felt, books, silk, nickel products, essential oils, and fish. 


\section{Czech and Slovak Republics}

Major declining exports (average annual growth rates of minus ten percent or more) are concentrated in $a_{o}$ riculture. Half of all products where exports to the EU declined are agricultural. Fish, preparations of vegetables, dairy products, and meat are among the major declining commodities. The largest absolute declines occurred for dairy and meat. Nonagricultural products where exports fell significantly include lead, ores, and wood pulp.

\section{Hungary}

Products that decline by 10 percent or more per year include vegetable saps, milled agricultural items, nickel products, cement, fish, fur, wool, ores and slag, fibers, fats, food residues, dairy products, and fertilizers. The largest absolute declines were registered for fertilizers and meat (each down by over 80 percent of 1989 exports); and iron and steel (down by 30 percent of 1989 exports). As for the Czech and Slovak Republics, agricultural goods and processed foodstuffs figure prominently in the decline in exports. Between 1989 and 1993 exports of declining agricultural items fell from ECU 600 million (one quarter of total exports) to ECU 475 million (12 percent of total exports to the EU).

\section{Poland}

About half of the 2-digit commodity groups registering declines are agricultural or foodstuffs. The latter account for most of the absolute reduction in exports experienced by the declining products: they were ECU 229 million lower in 1993 than in 1989, accounting for 85 percent of the declining group total. The only non-food related item =here exports fell by a laige amount is starihes and glues (down by 50 percent oi 1009 exports).

\section{Romania}

Declines in exports to the EU are reported for more products than for any other CEEC. Mineral fuels dominate the decline in absolute terms, falling from ECU 844 million in 1989 to ECU 37 million in 1993. There are only two agriculture items among the 12 worst performing products, dairy and meat. Both of these experience a dramatic fall in exports, diminishing over sevenfold between 1989 and 1993. Manufactured goods among the worst performers include paper and paperboard; manmade fibers; motor vehicles; wood products; iron and steel; furniture; and aluminum.

\section{FSU}

The largest absolute declines in exports to the EU occur for wood pulp, motor vehicles, wood products, and nickel products. Exports of these four items fall by almost ECU 1 billion between 1989 and 1993 (equal to about half of 1989 exports). Declines registered for many of the products where exports are large tend to be relatively small, however. Products where exports were almost flat include spirits, rubber articles, machinery, and organic chemicals.

\section{Sustainability of Export Growth}

One of the striking developments in the structure of exports of the CEECs during the last four years has been the convergence int specialization of exports to the EU that appears to have taken place. Correlations between specialization indices for countries in Eastern Europe are now quite high and have been rising where they had been low in 1993 (see Table 8 and Appendix Table 6). As of 1993, correlation coefficients between any of the CEECs were at least 0.2 , and for some country pairs were close to or above 0.5. Exports patterns are thus becoming increasingly similar. The same is true for the FSU, but from a lower base and a more recent starting point. 
Table 8: Relative specialization: correlation coefficients, 1993

\begin{tabular}{|lccccc|}
\hline & BUL & CSR & HUN & POL & ROM \\
Bulgaria & 1.00 & & & & \\
CSFR & 0.21 & 1.00 & & & \\
Hungary & 0.35 & 0.28 & 1.00 & & \\
Poland & 0.28 & 0.52 & 0.60 & 1.00 & \\
Romania & 0.24 & 0.45 & 0.33 & 0.49 & 1.00 \\
FSU & 0.20 & & & 0.19 & \\
& & & & & \\
\hline
\end{tabular}

An obvious question suggested by this finding-and the export performance of the CEECs more generally-concerns the importance of comparative advantage as opposed to trade policy. What role have the Europe Agreements played? ${ }^{21}$ The fact that the CEECs now have preferential access to protected markets (e.g., footwear, textiles and clothing) may be a determinant of what we observe. At the same time, quotas and tariffs on sensitive items may induce a shift towards non-sensitive products that have been granted free access into the EU.

Although the CEECs are specializing in many products where comparator countries have been confronted with contingent protection, the growth in the relative importance of intraindustry trade, and the ongoing diversification/differentiation of industrial exports--especially from the Czech Republic and Poland--suggests that the CEECs may have less to fear than their developing country competitors in this respect. ${ }^{22}$ The CEECs will gradually adopt EU laws and practices relating to competition, thereby reducing the scope for EU industries to invoke antidumping. ${ }^{23}$ Diversion of pressure for contingent protection may well turn out to be more important. Given the similarity between the CEECs and developing countries, the latter may come to face a more hostile trade policy environment in the future. Clothing producers in particular will face fierce competition from the CEECs in the next 5 years as their preferential access to the EU is maintained/strengthened.

\section{Conclusions}

Trade data suggest that a significant amount of restructuring has been achieved in the CEECs in the last four years. Although totai exports of these countries as a group have barely attained the levels of 1989 , a massive reorientation of trade towards the EU has occurred. Given the need to produce to high Western standards, while remaining price competitive, this reorientation must reflect restructuring at the firm level firm. This may or may not involve significant shedding of labor. It also does not necessarily imply large changes in the relative specialization of the economy. The CEECs demonstrate large differences in the extent to which changes in relative specialization occur, and in the magnitude of the shifts away from 'traditional' and towards 'new' products.

The trade data that have been discussed in this paper are perhaps most useful for crosscountry comparisons. Figur: 7 summarizes the main message that is suggested by the available data. It plots the change in per capita exports to the EU against the measure of change in the 'structure' of exports to the EU over the 198993 period. The Czech and Slovak Republics clearly outperform the other CEECs and the FSU by a substantial margin.

While all the CEECs have managed to increase their exports to the EU very substantially in the last four years (Romania being the exception), the Czech and Slovak Republics taken together are the most successful in this connection. In absolute terms, exports have grown the most, and they also dominate with respect to the number and importance of 'new' products in total exports. At the same time, the Czech and Slovak Republics report the fewest negative-growth products.

The large increase in the number of products exported to the EU and the growth in intra-industry trade suggests that a lot of 
Figure 7: Change in per capita exports to EC and Structural change in exports

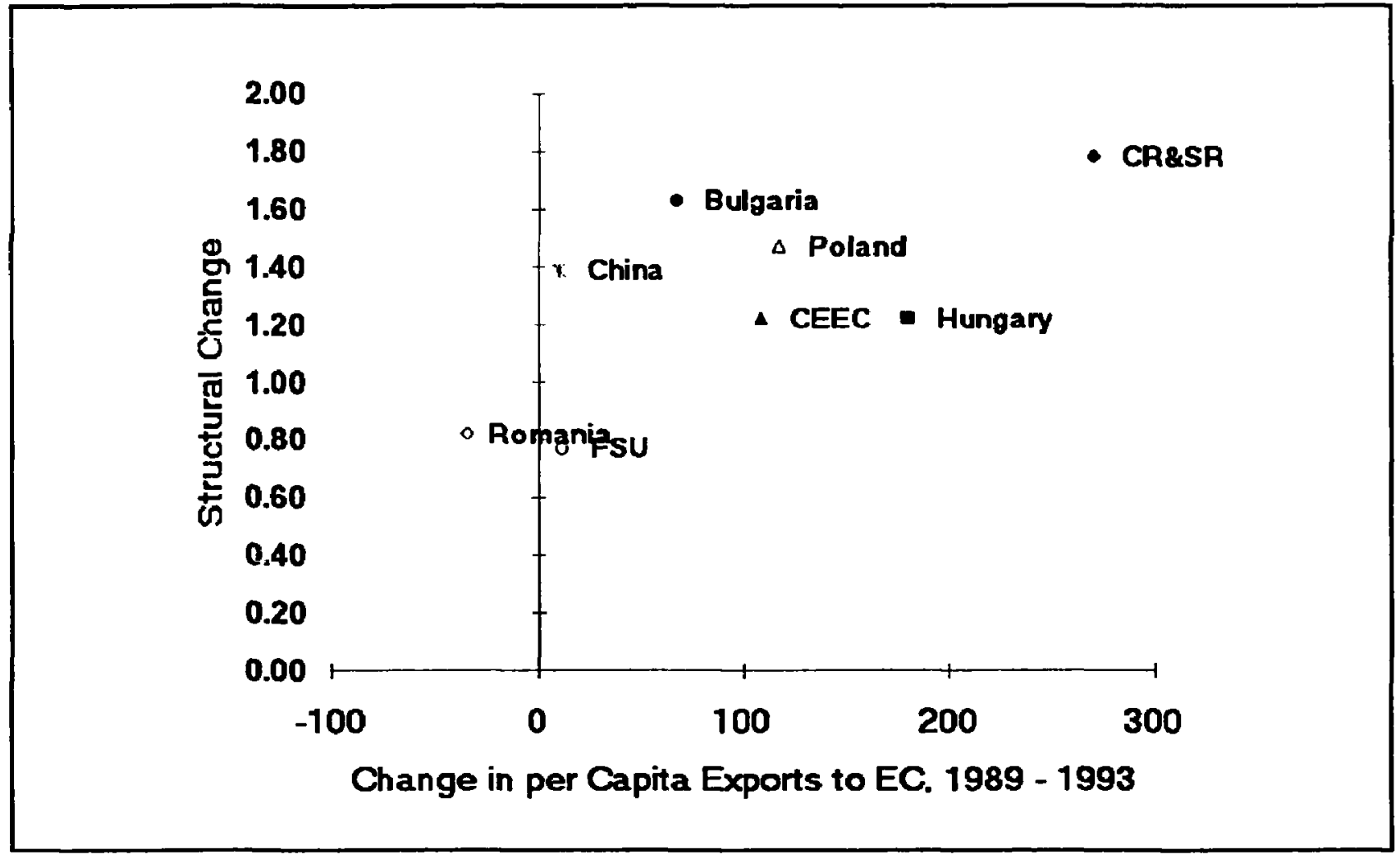

restructuring is happenning through product differentiation. Although aggregate measures of relative specialization have not changed very much for the Czech Republic, there have heen significant changes within the broad product groups that were already exported to the EU. A similar conclusion holds for Hungary and Poland, but Hungary's aggregate performance has been lagging.

It is, of course not possible to prove beyond all doubt cause and effect of industrial restructuring, revealed by these remarkable changes in export structure. But the data are, nevertheiess, suggestive. Among the CEECs, all countries have liberalized prices of manufactured goods early on in the reform process (between 1989 and 1991). Rapid changes in export structure and performance generally started immediately following price reform (see Appendix, Table 2), for example, in Hungary and Poland in 1990, in former Czechoslovakia in 1991, and in most of the FSU in 1993.
One would thus expect that the earliest reformers would have seen the largest change in trade structure during the four year period 1989 . 93. This is indeed the case, if one compares the CEEC average with the FSU average. But this is not the case in Central and Eastern Europe. The Czech and Slovak Republics show much more change and growth than Hungary and Poland. This could be either attributed to factor endowments, macro-economic policy, or different privatization strategies. All three probable played a role: Hungary had the most open economy before the reforms, and can thus be expected to show somewhat less change. It has also not used exchange rate adjustment as extensively as the other countries to increase export competitiveness. But it possibly does not matter all that much as wages are only $10 \%$ (Poland), 11\% (Czech and Slovak Republics) or 15\% (Hungary) of German wages, just across the border. 
Since Polish wages are not all that different from Czech and Slovak wage levels, credibility of privatization and reform strategies must have clearly played a major role. The same is true for Hungary. It's better starting point can explain the lesser change in export structure. But wage differentials cannot account for all the difference in export performance (Figure 7), and the fact that the Czech Republic has quickly by-passed Hungary as the most successful exporter (Figure 1).

The conclusion can be summarized as follows: mass-privatization has certainly stimulated at least as much (if not significantly more) industrial restructuring than case-by-case privatization with it's emphasis on "ideal" owners who have the restructuring know how. Technicians and managers, brought up under the old system, have proved to be quite successful in learning new management and marketing skills. Some pressure on all enterprises led economywide to much larger changes than extensive restructuring of only a few large firms. Foreign investment (initially concentrated in Hungary) has so far not had a large impact. Some restructuring has occurred everywhere even before privatization had been implemented. The collapse of central authority (Bulgaria, FSU) has been of economic benefit in the short run.

However, credible and comprehensive privatization and reform strategies are necessary to ensure a sustained restructuring effort. The reforms in the Czech Republic remain the standard by which other countries will have to be measured.

\section{References}

Aghion, Philippe, et al. 1992. "Towards and Integrated European Continental Common Market," in J. Flemming and J. Rollo (eds.), Trade, Payments and Adjustment in Central and Eastern Europe. London: Royal Institute for International Affairs.

Baldwin, Richard. 1994. Towards an Integrated Europe. London: CEPR.

Borensztein, E., D. Demekas, and J. Ostry. 1993. "Output Decline in the Aftermath of Reform: Bulgaria, Czechoslovakia, and Romania," in M. Blejer et al. (eds.), Eastern Europe in Transition: From Recession to Growth?. Discussion Paper 196. Washington D.C.: The World Bank.

Greenaway, David and Robert Hine. 1991. "Intra-Industry Specialization, Trade Expansion and Adjustment in the European Economic Space," Joumal of Common Market Studies, 29, 603-22.

Halpern, Lásl6. 1994. "Comparative Advantage and the Likely Trade Pattern of the CEECs," CEPR Discussion Paper 1003.

Hamilton, Carl and Alan Winters. 1992. "Trade with Eastern Europe," Economic Policy, 14:78-116.

Hoekman, Bernard and Petros C. Mavroidis. 1994. "Linking Trade and Competition Policies in Central and Eastern Europe," Policy Research Paper 1346, The World Bank.

Kaminski, Bartlomiej. 1994. "The Significance of the 'Europe Agreements' for Central European Industrial Exports," Policy Research Working Paper 1314, The World Bank.

Mastropasqua, Cristina and Valeria Rolli. 1994. 'Industrial Countries' Protectionism with 
Respect to Eastern Europe," The World

Economy, 17:151-69.

Messerlin, Patrick. 1993. "The EC and Central Europe: The missed rendezvous of 1992?," The Economics of Transition, 1, 89-110.

Naujoks, Petra and Klaus-Dieter Schmidt. 1994. "Outward Processing in Central and East European Transition Countries," Kiel Working Paper 631 (May).

Neven, Damien. 1990. "Gains and Losses from '1992'," Economic Policy, 10:13-62.

Neven, Damien. 1994. "Trade Liberalization with Eastern Nations: How Sensitive?," CEPR Discussion Paper 1000.

Pohl, Gerhard and Istvan Dobozi. 1995. "How Much Has Output Declined in Eastern Europe and the Former Soviet Union?," World Bank Mimeo

Pohl, Gerhard and Piritta Sorsa. 1992. European Integration and Trade with the Developing World. Policy and Research Series 21. Washington D.C.: The World Bank.

Rollo, Jim and Alasdair Smith. 1993. "The Political Economy of Eastern European Trade with the European Community: Why So Sensitive?," Economic Policy, 16:140-81.

Winters, L. Alan. 1992. "The Europe Agreements: With a Little Help from Our Friends," in The Association Process: Making it Work. London: Center for Economic and Policy Research. 
1. Reported GDP numbers and Growth rates are highly unreliable. Simple quantitative indicators, such as electric power consumption changes may be for more reliable (see Pohl and Dobozi, 1995).

2. While official GDP estimates indicate a cumulative decline in economic activity of $21 \%$ during 1989-94 for both the Czech Republic and Hungary, electric power consumption in the Czech Republic declined by only $11 \%$ but in Hungary by $18 \%$ during the same period. This is probably a more consistent estimate.

3. See, for example, Messerlin (1993); Pohl and Sorsa (1992), and Winters (1992).

4. The data used are the most detailed, disaggregated trade figures that are available from the statistical office of the European Communities (EUROSTAT) on a comparable basis: 8-digit Combined Nomenclature (CN), the EU's version of the Harmonized System, or about 9,750 items. The COMEXT CD-ROM database was used. It should be noted that the use of EU import data to infer CEEC exports will inflate the level of exports as the EU values imports on a c.i.f. basis, i.e., inclusive of freight and insurance. It should also be noted that there are numerous instances where reported imports by the EU are zero in 1989, but are quite large in 1993. To take just one example, exports of copper and siiver from Bulgaria to the EU was reported to be zero in 1989, and to have grown to more than ECU 20 million in 1993. In the discussion that follows this will be interpreted as a reorientation of trade. However, at this level of disaggregation it is quite possible that values for specific items are zero for one or more years and that there may be inaccuracies in recording trade flows.

5. The main exception is Bulgaria. Thus, while Bulgaria has been able to reorient itself towards the EU-it was heavily dependent on the USSR-this has taken place in the context of a severe fall in output. Total trade is still below the level of the late 1980s.

6. Aggregate data for the Czech and Slovak Republics are used in most of what follows in order to maintain comparability. The same reasoning applies to the FSU, with the added rationale that this allows us to avoid dealing with issues of transshipment and arbitrage activities. Separate trade data for the Czech Republic and Slovakia are available for 1993 only. They reveal that the Czech Republic now accounts for $\mathbf{8 0}$ percent of the combined exports. The composition of exports is also similar, with the following exceptions: Slovakia is much more specialized in clothing and steel production (14 and 19 percent of total exports in 1993, as compared to 8.5 and 12 percent for the Czech Republic), while the Czech's are more specialized in machinery and transport equipment (18.5 and 9 percent, versus 10 and 6 percent for Slovakia).

7. It should be noted that there are valuation problems here, both wich respect to absolute value of exports in 1989 and as regards year-to-year changes (the latter due to variations in the ECU/dollar exchange rate). The data for total exports in 1989 for Bulgaria, the Czechil and Slovak Republics and Romania have been adjusted ior the overvaluation that results if official 'exchange rates' for convertible rubles are used. It should also be kept in mind that by using EU import data, implied exports from the CEECs are overvalued by the inclusion of freight and insurance. 
8. The CSFR had the greatest dependence on the CMEA: some 80 percent of its exports went to centrally-planned economies, as opposed to 50 percent for Hungary, and 40 percent for Poland (Halpern, 1994). It should be noted that as of the end of 1990, the German Democratic Republic's external trade is included in that of Germany in the EU's database. There is consequently a one-time upward shift in the EU's imports from the CEECs.

9. These figures are in constant 1988 dollars to ensure comparability with those reported by Mastropasqua and Rolli (1994).

10. The sample includes the CEECs, the FSU, Turkey, China, South Korea, North Africa, and the Middle East. The change in the structure of exports is defined as:

$$
\frac{\sum_{i=1}^{K}\left|a_{i 89}-a_{193}\right|}{\sum_{i=1}^{K} a_{i 69}}
$$

where $a_{i}$ is the value of exports of an 8-digit $C N$ item in 1989 and 1993 , respectively, and $K$ is the number of commodities exported.

11. The structural change in the FSU accelerated significantly in 1993. See Appendix Table 2. It can be observed that on a year-to-year basis the largest values of changes in exports appear to occur in years where price liberalization occurred, i.e., 1990 for Hungary and Poland; 1991 for the Czech and Slovak Republics; and 1993 for much of the FSU.

12. In the case of 'expired' commodities, the denominator used is total exports of the previous year; in the case of new products, the denominator is total exports for the current year. Data can be found in Appendix Table 3.

13. Relative specialization is defined as:

$$
\frac{x_{i j} / X_{j}}{\sum_{j=1}^{w} x_{j} / \sum_{j=1}^{w} X}
$$

where $x_{i j}$ are exports of commodity $i$ by country $j, X_{j}$ are country $j$ 's total exports, and $N$ is the number of countries. Usually this indicator, often called the revealed comparative advantage (RCA) index, is defined for the world, i.e., the denominator would sum across all countries. In the case of this paper however, specialization indices have been defined relative to total EU imports. Thus, the denominator consists of total EU imports of commodity $i$, divided by total EU imports of all commodities. Intra-EU trade is excluded because intra-EU trade is not available for 1993.

14. Under central planning, Bulgaria became increasingly specialized in heavy industries such as steel, and machinery and equipment. With the decline of Eastern markets, these products could not be sold on Western markets (Borensztein et al. 1993). The shift towards lighter industry revealed by the export data therefore represents restructuring. 
15. Intra-industry trade is often calculated using the Grubel-Lloyd measure, which is defined as:

$$
1-\frac{\sum_{1}\left|X_{1}-M_{1}\right|}{\sum_{l}\left(X_{1}+M_{1}\right)}
$$

where $X_{i}$ and $M_{i}$ are a country's exports to--and imports from-a trading partner of commodity $i$, respectively. The closer to one, the higher is intra-industry trade.

16. See Greenaway and Hine (1991) for a recent survey of the theory and evidence in the EU context. This is not to say that intra-industry trade will not lead to adjustment and thus pressure for protection. To the extent that there are specific and relatively immobile factors of production that are injured by import competition, they can be expected to seek protection. But the factors that are hurt will be at the firm-level. Other firms in the industry will expand. This makes it more difficult to obtain protection, as there will be corfificting interests within industries.

17. Processing trade has even expanded to agricultural goods. Almost 5 percent of Poland's agricultural exports to the EU enter under the outward processing regime. Apparently this is mostly due to the German fish industry shipping raw crustaceans to Poland for shelling be hand (Naujoks and Schmidt, 1994).

18. Subcontracting activities are important here. Their share in total exports increased from 4 to 19 percent, and 2 to 13 percent for machinery and instruments, respectively, in the 1989-93 period.

19. Greater than ECU 10 million in 1989.

20. Note that these calculations assume that the zero imports reported by the EU for a nimber of the goods in question reflect reality.

21. See Rollo and Smith (1993) and Kaminski (1994) for more detailed analyses.

22. See Neven (1994) for a detailed and careful analysis of the likely political economy of pressures for contingent protection in the EU against the CEECs. Romania has a lot of competitor countries that have a somewhat similar pattern of exports to the EU. These countries include the Philippines, China, Turkey, Hong Kong, and Taiwan. Presumably this reflects the great increase in relative specialization in textiles and clothing in Romania. In the case of Hungary Mexico and Brazil have become 'competitors', while the Czech and Slovak Republics have become more similar to Turkey and Taiwan. Poland's pattern of relative specialization does not appear to be similar to any of the countries chosen as potential comparators, with the exception of the FSU. The 1993 correlation coefficient between Poland-FSU is 0.19, up from zero in 1989.

23. Any rationale for the maintenance of antidumping in EU-CEEC trade disappears once the CEECs have abolished trade barriers and adopted the EU's competition policies. As argued at greater length in Hoekman and Mavroidis (1994), efforts should be made to link the elimination of antidumping to the full implementation of the Europe Agreements. 
Appendix Table 1

Exports to the EU, 1989 and 1993

(ECU million and percentage)

\begin{tabular}{|c|c|c|c|c|c|c|c|c|c|}
\hline Counity / Group & $\begin{array}{l}\text { Value } \\
1989\end{array}$ & $\begin{array}{l}\text { Value } \\
1993\end{array}$ & $\begin{array}{l}\text { Market } \\
\text { Share in } \\
\text { EU } \\
1989\end{array}$ & $\begin{array}{c}\text { Market } \\
\text { Share in } \\
\text { EU } \\
1993\end{array}$ & $\begin{array}{c}\text { Average } \\
\text { Annual } \\
\text { Change in } \\
\text { Exports to } \\
\text { EU } \\
\text { 1989-93 }\end{array}$ & $\begin{array}{c}\text { Export/ } \\
\text { GDP } \\
1993\end{array}$ & $\begin{array}{c}\text { Predicted } \\
\text { Export/GDP* }\end{array}$ & $\begin{array}{c}\text { EU Share } \\
\text { in Total } \\
\text { Exports }\end{array}$ & $\begin{array}{l}\text { Predicted } \\
\text { EU Share } \\
\text { of Total } \\
\text { Exports** }\end{array}$ \\
\hline $\begin{array}{l}\text { Bulgaria } \\
\text { Czech \& Slovak Rep. } \\
\text { Hungary } \\
\text { Poland } \\
\text { Romania }\end{array}$ & $\begin{array}{r}523 \\
2,521 \\
2,571 \\
3,817 \\
2,531\end{array}$ & $\begin{array}{r}944 \\
5,981 \\
3,931 \\
7,505 \\
1,670\end{array}$ & $\begin{array}{l}0.12 \\
0.56 \\
0.58 \\
0.85 \\
0.57\end{array}$ & $\begin{array}{l}0.19 \\
1.23 \\
0.81 \\
1.54 \\
0.34\end{array}$ & $\begin{array}{l}15.9 \\
24.1 \\
11.1 \\
18.4 \\
-9.9\end{array}$ & $\begin{array}{l}35.1 \\
31.9 \\
23.4 \\
16.2 \\
19.7\end{array}$ & $\begin{array}{l}21 \\
28 \\
31 \\
19 \\
23\end{array}$ & $\begin{array}{l}30.4 \\
52.4 \\
51.8 \\
62.2 \\
40.0\end{array}$ & $\begin{array}{l}44.6 \\
65.0 \\
64.0 \\
55.0 \\
48.0\end{array}$ \\
\hline FSU & 13,258 & 15,457 & 2.97 & 3.18 & 3.9 & 10.6 & 9 & 32.4 & 50.0 \\
\hline $\begin{array}{l}\text { China } \\
\text { South Korea }\end{array}$ & $\begin{array}{l}9,077 \\
6,925\end{array}$ & $\begin{array}{r}19,491 \\
7,690\end{array}$ & $\begin{array}{l}2.03 \\
1.55\end{array}$ & $\begin{array}{l}4.01 \\
1.58\end{array}$ & $\begin{array}{r}21.1 \\
2.7\end{array}$ & $\begin{array}{l}17.7 \\
24.9\end{array}$ & & & \\
\hline $\begin{array}{l}\text { Turkey } \\
\text { Morocco }\end{array}$ & $\begin{array}{l}5,509 \\
2,677\end{array}$ & $\begin{array}{l}6,530 \\
3,195\end{array}$ & $\begin{array}{l}1.23 \\
0.60\end{array}$ & $\begin{array}{l}1.34 \\
0.66\end{array}$ & $\begin{array}{l}4.3 \\
4.5\end{array}$ & $\begin{array}{l}13.0 \\
13.9\end{array}$ & & & \\
\hline $\begin{array}{l}\text { CEECs } \\
\text { MENA }\end{array}$ & $\begin{array}{l}11,964 \\
26,595\end{array}$ & $\begin{array}{l}20,030 \\
29,537\end{array}$ & $\begin{array}{l}2.68 \\
5.95\end{array}$ & $\begin{array}{l}4.12 \\
6.08\end{array}$ & $\begin{array}{r}13.7 \\
2.7\end{array}$ & & & & \\
\hline
\end{tabular}

- Hamilton and Winters (1992).

** Baldwin (1994). 
Appendix Table 2

Total Change in Structure of Exports

(8 digit 'evel)

\begin{tabular}{|l|r|r|r|r|r|r||}
\hline \multicolumn{1}{|c|}{ Country / Group } & $\begin{array}{c}1989- \\
1990\end{array}$ & $\begin{array}{c}1990- \\
1991\end{array}$ & $\begin{array}{c}1991- \\
1992\end{array}$ & $\begin{array}{c}1992- \\
1993\end{array}$ & $\begin{array}{c}\text { Change } \\
89-93\end{array}$ & $\begin{array}{c}\text { \% of change } \\
\text { due to } \\
\text { growth }\end{array}$ \\
\hline Bulgaria & 1.49 & 1.71 & 1.26 & 1.10 & 1.53 & 71.5 \\
Czech and Slovak Rep. & 0.85 & 1.60 & 1.03 & 0.76 & 1.67 & 83.6 \\
Hungary & 1.04 & 1.05 & 0.79 & 0.81 & 1.14 & 68.9 \\
Poland & 1.35 & 1.01 & 0.76 & 0.79 & 1.38 & 78.7 \\
Romania & 1.11 & 0.86 & 0.93 & 0.89 & 0.71 & 31.9 \\
& 0.60 & 0.67 & 0.81 & 1.33 & 0.72 & 59.4 \\
FSU & 0.91 & 1.09 & 0.55 & 0.58 & 1.30 & \\
China & 0.95 & 0.82 & 0.86 & 0.80 & 0.91 & \\
South Korea & 0.93 & 0.73 & 0.64 & 0.52 & 0.77 & \\
Turkey & 0.83 & 0.87 & 0.64 & 0.65 & 0.80 & \\
Morocco & & & & & \\
& & & & & \\
\hline
\end{tabular}

Note: See iext for the definition of this variable. All variables are expressed relative the annual mean. 
Appendix Tahle 3

Relative Importance of Expired and New Commodities

(percent)

\begin{tabular}{|c|c|c|c|c|c|}
\hline & 1990 & 1991 & 1992 & 1993 & $1989-93$ \\
\hline Bulgaria & $\begin{array}{r}6.91 \\
12.86\end{array}$ & $\begin{array}{l}10.65 \\
12.56\end{array}$ & $\begin{array}{l}9.33 \\
8.26\end{array}$ & $\begin{array}{l}9.48 \\
9.96\end{array}$ & $\begin{array}{l}23.7 \\
31.8\end{array}$ \\
\hline Czech \& Slovak Rep. & $\begin{array}{l}3.45 \\
4.18\end{array}$ & $\begin{array}{l}3.27 \\
7.40\end{array}$ & $\begin{array}{l}2.99 \\
2.48\end{array}$ & $\begin{array}{l}3.48 \\
5.37\end{array}$ & $\begin{array}{l}11.5 \\
19.8\end{array}$ \\
\hline Hungary & $\begin{array}{l}4.16 \\
5.10\end{array}$ & $\begin{array}{l}2.44 \\
3.41\end{array}$ & $\begin{array}{l}2.68 \\
3.11\end{array}$ & $\begin{array}{l}8.09 \\
8.27\end{array}$ & $\begin{array}{l}18.6 \\
20.7\end{array}$ \\
\hline Poland & $\begin{array}{l}4.46 \\
6.28\end{array}$ & $\begin{array}{l}1.76 \\
2.37\end{array}$ & $\begin{array}{l}1.65 \\
2.28\end{array}$ & $\begin{array}{l}4.62 \\
5.27\end{array}$ & $\begin{array}{l}13.8 \\
15.7\end{array}$ \\
\hline Romania & $\begin{array}{l}5.46 \\
4.15\end{array}$ & $\begin{array}{l}3.63 \\
5.35\end{array}$ & $\begin{array}{l}5.53 \\
5.79\end{array}$ & $\begin{array}{l}6.17 \\
7.47\end{array}$ & $\begin{array}{l}23.9 \\
18.0\end{array}$ \\
\hline FSU & $\begin{array}{l}1.38 \\
0.86\end{array}$ & $\begin{array}{l}0.96 \\
2.94\end{array}$ & $\begin{array}{l}8.46 \\
1.29\end{array}$ & $\begin{array}{l}1.89 \\
3.72\end{array}$ & $\begin{array}{l}7.9 \\
9.5\end{array}$ \\
\hline China & $\begin{array}{l}1.49 \\
1.79\end{array}$ & $\begin{array}{l}0.66 \\
1.05\end{array}$ & $\begin{array}{l}2.54 \\
2.67\end{array}$ & $\begin{array}{l}4.04 \\
3.66\end{array}$ & $\begin{array}{r}7.9 \\
10.8\end{array}$ \\
\hline South Korea & $\begin{array}{l}5.52 \\
6.94\end{array}$ & $\begin{array}{l}2.38 \\
1.9 i\end{array}$ & $\begin{array}{l}7.89 \\
7.82\end{array}$ & $\begin{array}{l}6.48 \\
6.90\end{array}$ & $\begin{array}{l}17.3 \\
18.4\end{array}$ \\
\hline Turkey & $\begin{array}{l}3.62 \\
3.84\end{array}$ & $\begin{array}{l}1.93 \\
1.71\end{array}$ & $\begin{array}{l}3.23 \\
2.20\end{array}$ & $\begin{array}{l}5.29 \\
4.65\end{array}$ & $\begin{array}{l}12.7 \\
10.7\end{array}$ \\
\hline Morocco & $\begin{array}{l}2.56 \\
2.32\end{array}$ & $\begin{array}{l}8.31 \\
7.99\end{array}$ & $\begin{array}{l}3.72 \\
3.61\end{array}$ & $\begin{array}{r}11.82 \\
5.42\end{array}$ & $\begin{array}{l}16.7 \\
15.8\end{array}$ \\
\hline
\end{tabular}

Note: The first line for each country is the share of exports in the previous year that disappeared; the second line for each country is the share of exports in the current year that is accounted for by 'new' products. The first row of the 1989-93 column is relative to 1989; the second row is relative to 1993 total exports. 
Appendix Table 4: Share of 'Traditional' Products in Total Exports, 1989-93 (ECU million and percentage)

\begin{tabular}{|c|c|c|c|c|c|c|}
\hline & \multicolumn{3}{|c|}{ 8-Digit Products > ECU 3 million in 1989} & \multicolumn{3}{|c|}{8 Digit Products < ECU 3 million in 1989} \\
\hline & 1989 & 1993 & $\begin{array}{c}\text { Annual } \\
\text { Average } \\
\text { Change }\end{array}$ & 1989 & 1993 & $\begin{array}{l}\text { Antral } \\
\text { Arerage } \\
\text { Change }\end{array}$ \\
\hline Bulgaria & $\begin{array}{r}230 \\
(44.0)\end{array}$ & $\begin{array}{r}182 \\
(19.3)\end{array}$ & -5.6 & $\begin{array}{r}293 \\
(56.0)\end{array}$ & $\begin{array}{r}761 \\
(80.7)\end{array}$ & 27.0 \\
\hline CSR & $\begin{array}{r}1,519 \\
(60.3) \\
\end{array}$ & $\begin{array}{l}1,784 \\
(29.8) \\
\end{array}$ & 4.1 & $\begin{array}{r}1,002 \\
(39.7) \\
\end{array}$ & $\begin{array}{l}4,197 \\
(70.2) \\
\end{array}$ & 43.1 \\
\hline Kungary & $\begin{array}{r}1,513 \\
(58.9)\end{array}$ & $\begin{array}{r}1,057 \\
(35.4) \\
\end{array}$ & -2.1 & $\begin{array}{r}1,390 \\
(41.1) \\
\end{array}$ & $\begin{array}{l}2,541 \\
(64.6) \\
\end{array}$ & 24.5 \\
\hline Poland & $\begin{array}{l}2,843 \\
(74.5)\end{array}$ & $\begin{array}{r}974 \\
(49.9)\end{array}$ & 7.2 & $\begin{array}{l}3,748 \\
(28.5)\end{array}$ & $\begin{array}{l}3,757 \\
(50.1)\end{array}$ & 40.1 \\
\hline Romania & $\begin{array}{r}2,036 \\
(80.4) \\
\end{array}$ & $\begin{array}{r}860 \\
(51.5) \\
\end{array}$ & -19.4 & $\begin{array}{r}496 \\
(19.6) \\
\end{array}$ & $\begin{array}{r}810 \\
(48.5) \\
\end{array}$ & 13.1 \\
\hline FSU & $\begin{array}{r}12,704 \\
(95.8)\end{array}$ & $\begin{array}{r}12,295 \\
-\quad(79.5)\end{array}$ & -0.8 & $\begin{array}{r}553 \\
(4.4)\end{array}$ & $\begin{array}{l}3,162 \\
(20.5)\end{array}$ & 54.6 \\
\hline
\end{tabular}

Figures in parentheses are shares in total exports. 
Appendix Table 5: Relative Specialization of Exports to the EU, 1989 and 1993

\begin{tabular}{|c|c|c|c|c|c|c|c|c|c|c|c|c|c|c|}
\hline & Agric. & $\begin{array}{l}\text { Oresl } \\
\text { Chem. }\end{array}$ & Leather & Wood & Fibers & Clothing & $\begin{array}{l}\text { Clayi } \\
\text { Glass } \\
\end{array}$ & $\begin{array}{l}\text { Iron/ } \\
\text { Steel } \\
\end{array}$ & $\begin{array}{l}\text { Nonfer. } \\
\text { Metals }\end{array}$ & Machines & $\begin{array}{l}\text { Transp. } \\
\text { Equip. }\end{array}$ & $\begin{array}{l}\text { Instru- } \\
\text { ments }\end{array}$ & Arms & $\begin{array}{c}\text { Furni- } \\
\text { ture }\end{array}$ \\
\hline Bulgaria & $\begin{array}{l}2.51 \\
1.95\end{array}$ & $\begin{array}{l}0.93 \\
0.75\end{array}$ & $\begin{array}{l}0.83 \\
3.50\end{array}$ & $\begin{array}{l}0.67 \\
0.56\end{array}$ & $\begin{array}{l}0.90 \\
1.66\end{array}$ & $\begin{array}{l}2.01 \\
3.01\end{array}$ & $\begin{array}{l}0.43 \\
1.04\end{array}$ & $\begin{array}{l}3.96 \\
1.35\end{array}$ & $\begin{array}{l}0.56 \\
3.02\end{array}$ & $\begin{array}{l}0.55 \\
0.45\end{array}$ & $\begin{array}{l}0.10 \\
0.07\end{array}$ & $\begin{array}{l}0.17 \\
0.18\end{array}$ & $\begin{array}{l}1.28 \\
0.16\end{array}$ & $\begin{array}{l}2.24 \\
1.23\end{array}$ \\
\hline CZSL & $\begin{array}{l}0.94 \\
0.51\end{array}$ & $\begin{array}{l}0.95 \\
0.72\end{array}$ & $\begin{array}{l}1.24 \\
1.70\end{array}$ & $\begin{array}{l}1.80 \\
1.08\end{array}$ & $\begin{array}{l}1.39 \\
1.65\end{array}$ & $\begin{array}{l}1.40 \\
1.51\end{array}$ & $\begin{array}{l}1.72 \\
1.19\end{array}$ & $\begin{array}{l}4.98 \\
5.40\end{array}$ & $\begin{array}{l}0.11 \\
0.94\end{array}$ & $\begin{array}{l}0.41 \\
0.66\end{array}$ & $\begin{array}{l}0.89 \\
1.09\end{array}$ & $\begin{array}{l}0.28 \\
0.29\end{array}$ & $\begin{array}{l}7.62 \\
1.85\end{array}$ & $\begin{array}{l}3.61 \\
4.60\end{array}$ \\
\hline Hungary & $\begin{array}{l}3.20 \\
2.11\end{array}$ & $\begin{array}{l}0.63 \\
0.55\end{array}$ & $\begin{array}{l}2.39 \\
2.60\end{array}$ & $\begin{array}{l}0.53 \\
0.55\end{array}$ & $\begin{array}{l}0.89 \\
0.73\end{array}$ & $\begin{array}{l}2.80 \\
2.54\end{array}$ & $\begin{array}{l}0.53 \\
0.51\end{array}$ & $\begin{array}{l}2.43 \\
2.30\end{array}$ & $\begin{array}{l}1.12 \\
1.43\end{array}$ & $\begin{array}{l}0.54 \\
0.87\end{array}$ & $\begin{array}{l}0.15 \\
0.40\end{array}$ & $\begin{array}{l}0.15 \\
0.23\end{array}$ & $\begin{array}{l}1.29 \\
0.64\end{array}$ & $\begin{array}{l}3.25 \\
2.92\end{array}$ \\
\hline Poland & $\begin{array}{l}2.55 \\
1.26\end{array}$ & $\begin{array}{l}0.92 \\
0.73\end{array}$ & $\begin{array}{l}1.21 \\
1.19\end{array}$ & $\begin{array}{l}0.72 \\
1.17\end{array}$ & $\begin{array}{l}0.37 \\
0.55\end{array}$ & $\begin{array}{l}2.11 \\
2.70\end{array}$ & $\begin{array}{l}0.59 \\
0.45\end{array}$ & $\begin{array}{l}3.01 \\
3.21\end{array}$ & $\begin{array}{l}2.02 \\
2.30\end{array}$ & $\begin{array}{l}0.35 \\
0.35\end{array}$ & $\begin{array}{l}0.67 \\
1.33\end{array}$ & $\begin{array}{l}0.11 \\
0.12\end{array}$ & $\begin{array}{l}0.56 \\
0.08\end{array}$ & $\begin{array}{l}4.70 \\
6.25\end{array}$ \\
\hline Romania & $\begin{array}{l}0.43 \\
0.56\end{array}$ & $\begin{array}{l}1.61 \\
0.39\end{array}$ & $\begin{array}{l}0.91 \\
4.20\end{array}$ & $\begin{array}{l}0.56 \\
0.41\end{array}$ & $\begin{array}{l}0.61 \\
0.77\end{array}$ & $\begin{array}{l}3.57 \\
5.77\end{array}$ & $\begin{array}{l}0.54 \\
0.56\end{array}$ & $\begin{array}{l}2.12 \\
2.16\end{array}$ & $\begin{array}{l}1.56 \\
0.29\end{array}$ & $\begin{array}{l}0.20 \\
0.29\end{array}$ & $\begin{array}{l}0.24 \\
0.31\end{array}$ & $\begin{array}{l}0.05 \\
0.10\end{array}$ & $\begin{array}{l}0.02 \\
0.44\end{array}$ & $\begin{array}{l}17.82 \\
13.07\end{array}$ \\
\hline FSU & $\begin{array}{l}0.18 \\
0.36\end{array}$ & $\begin{array}{l}2.57 \\
2.48\end{array}$ & $\begin{array}{l}0.52 \\
0.68\end{array}$ & $\begin{array}{l}1.09 \\
0.74\end{array}$ & $\begin{array}{l}0.85 \\
1.88\end{array}$ & $\begin{array}{l}0.04 \\
0.27\end{array}$ & $\begin{array}{l}1.31 \\
1.14\end{array}$ & $\begin{array}{l}1.21 \\
1.68\end{array}$ & $\begin{array}{l}2.63 \\
5.54\end{array}$ & $\begin{array}{l}0.05 \\
0.05\end{array}$ & $\begin{array}{l}0.36 \\
0.24\end{array}$ & $\begin{array}{l}0.07 \\
0.06\end{array}$ & $\begin{array}{l}1.12 \\
0.49\end{array}$ & $\begin{array}{l}0.27 \\
0.43\end{array}$ \\
\hline China & $\begin{array}{l}1.15 \\
0.69\end{array}$ & $\begin{array}{l}0.53 \\
0.37\end{array}$ & $\begin{array}{l}4.49 \\
5.22\end{array}$ & $\begin{array}{l}0.37 \\
0.37\end{array}$ & $\begin{array}{l}3.69 \\
1.48\end{array}$ & $\begin{array}{l}4.04 \\
3.30\end{array}$ & $\begin{array}{l}0.44 \\
0.42\end{array}$ & $\begin{array}{l}0.62 \\
0.67\end{array}$ & $\begin{array}{l}0.22 \\
0.31\end{array}$ & $\begin{array}{l}1.21 \\
1.43\end{array}$ & $\begin{array}{l}0.08 \\
0.08\end{array}$ & $\begin{array}{l}0.62 \\
0.83\end{array}$ & $\begin{array}{l}0.35 \\
0.22\end{array}$ & $\begin{array}{l}1.36 \\
2.21\end{array}$ \\
\hline $\begin{array}{l}\text { South } \\
\text { Korea }\end{array}$ & $\begin{array}{l}0.16 \\
0.15\end{array}$ & $\begin{array}{l}0.20 \\
0.38\end{array}$ & $\begin{array}{l}7.30 \\
3.89\end{array}$ & $\begin{array}{l}0.10 \\
0.11\end{array}$ & $\begin{array}{l}1.51 \\
1.68\end{array}$ & $\begin{array}{l}3.38 \\
1.38\end{array}$ & $\begin{array}{l}0.39 \\
0.25\end{array}$ & $\begin{array}{l}0.75 \\
1.00\end{array}$ & $\begin{array}{l}0.07 \\
0.15\end{array}$ & $\begin{array}{l}2.04 \\
1.83\end{array}$ & $\begin{array}{l}0.54 \\
1.76\end{array}$ & $\begin{array}{l}0.79 \\
0.79\end{array}$ & $\begin{array}{l}0.10 \\
0.33\end{array}$ & $\begin{array}{l}0.28 \\
0.11\end{array}$ \\
\hline Turkey & $\begin{array}{l}1.57 \\
1.85\end{array}$ & $\begin{array}{l}0.64 \\
0.35\end{array}$ & $\begin{array}{l}3.35 \\
2.45\end{array}$ & $\begin{array}{l}0.03 \\
0.07\end{array}$ & $\begin{array}{l}4.41 \\
3.38\end{array}$ & $\begin{array}{l}7.43 \\
7.63\end{array}$ & $\begin{array}{l}0.62 \\
0.5 y\end{array}$ & $\begin{array}{l}1.70 \\
0.72\end{array}$ & $\begin{array}{l}0.48 \\
0.43\end{array}$ & $\begin{array}{l}0.20 \\
0.29\end{array}$ & $\begin{array}{l}0.21 \\
0.33\end{array}$ & $\begin{array}{l}0.07 \\
0.07\end{array}$ & $\begin{array}{l}1.15 \\
2.05\end{array}$ & $\begin{array}{l}0.48 \\
0.55\end{array}$ \\
\hline Morocco & $\begin{array}{l}2.93 \\
2.76\end{array}$ & $\begin{array}{l}0.96 \\
0.68\end{array}$ & $\begin{array}{l}1.97 \\
1.67\end{array}$ & $\begin{array}{l}0.32 \\
0.19\end{array}$ & $\begin{array}{l}0.66 \\
0.64\end{array}$ & $\begin{array}{l}7.02 \\
6.80\end{array}$ & $\begin{array}{l}0.28 \\
0.17\end{array}$ & $\begin{array}{l}0.16 \\
0.18\end{array}$ & $\begin{array}{l}0.40 \\
0.36\end{array}$ & $\begin{array}{l}0.19 \\
0.28\end{array}$ & $\begin{array}{l}0.34 \\
0.09\end{array}$ & $\begin{array}{l}0.05 \\
0.08\end{array}$ & $\begin{array}{l}0.01 \\
0.13\end{array}$ & $\begin{array}{l}0.29 \\
0.15\end{array}$ \\
\hline Israel & $\begin{array}{l}2.43 \\
1.98\end{array}$ & $\begin{array}{l}1.04 \\
1.09\end{array}$ & $\begin{array}{l}0.24 \\
0.18\end{array}$ & $\begin{array}{l}0.16 \\
0.18\end{array}$ & $\begin{array}{l}1.66 \\
1.42\end{array}$ & $\begin{array}{l}1.91 \\
1.66\end{array}$ & $\begin{array}{l}3.88 \\
2.15\end{array}$ & $\begin{array}{l}0.19 \\
0.16\end{array}$ & $\begin{array}{l}0.42 \\
0.74\end{array}$ & $\begin{array}{l}0.58 \\
0.82\end{array}$ & $\begin{array}{l}0.18 \\
0.13\end{array}$ & $\begin{array}{l}1.03 \\
1.19\end{array}$ & $\begin{array}{l}4.49 \\
0.54\end{array}$ & $\begin{array}{l}0.77 \\
0.78\end{array}$ \\
\hline Egypt & $\begin{array}{l}0.38 \\
0.61\end{array}$ & $\begin{array}{l}2.80 \\
2.89\end{array}$ & $\begin{array}{l}0.06 \\
0.17\end{array}$ & $\begin{array}{l}0.01 \\
0.03\end{array}$ & $\begin{array}{l}3.89 \\
4.20\end{array}$ & $\begin{array}{l}0.49 \\
1.06\end{array}$ & $\begin{array}{l}0.11 \\
0.12\end{array}$ & $\begin{array}{l}0.72 \\
0.41\end{array}$ & $\begin{array}{l}2.32 \\
1.46\end{array}$ & $\begin{array}{l}0.04 \\
0.08\end{array}$ & $\begin{array}{l}0.28 \\
0.52\end{array}$ & $\begin{array}{l}0.06 \\
0.14\end{array}$ & $\begin{array}{l}0.02 \\
0.14\end{array}$ & $\begin{array}{l}0.07 \\
0.23\end{array}$ \\
\hline
\end{tabular}


Appendix Table 6

Relative Specialization: Correlation Coefficients, 1989 and 1993

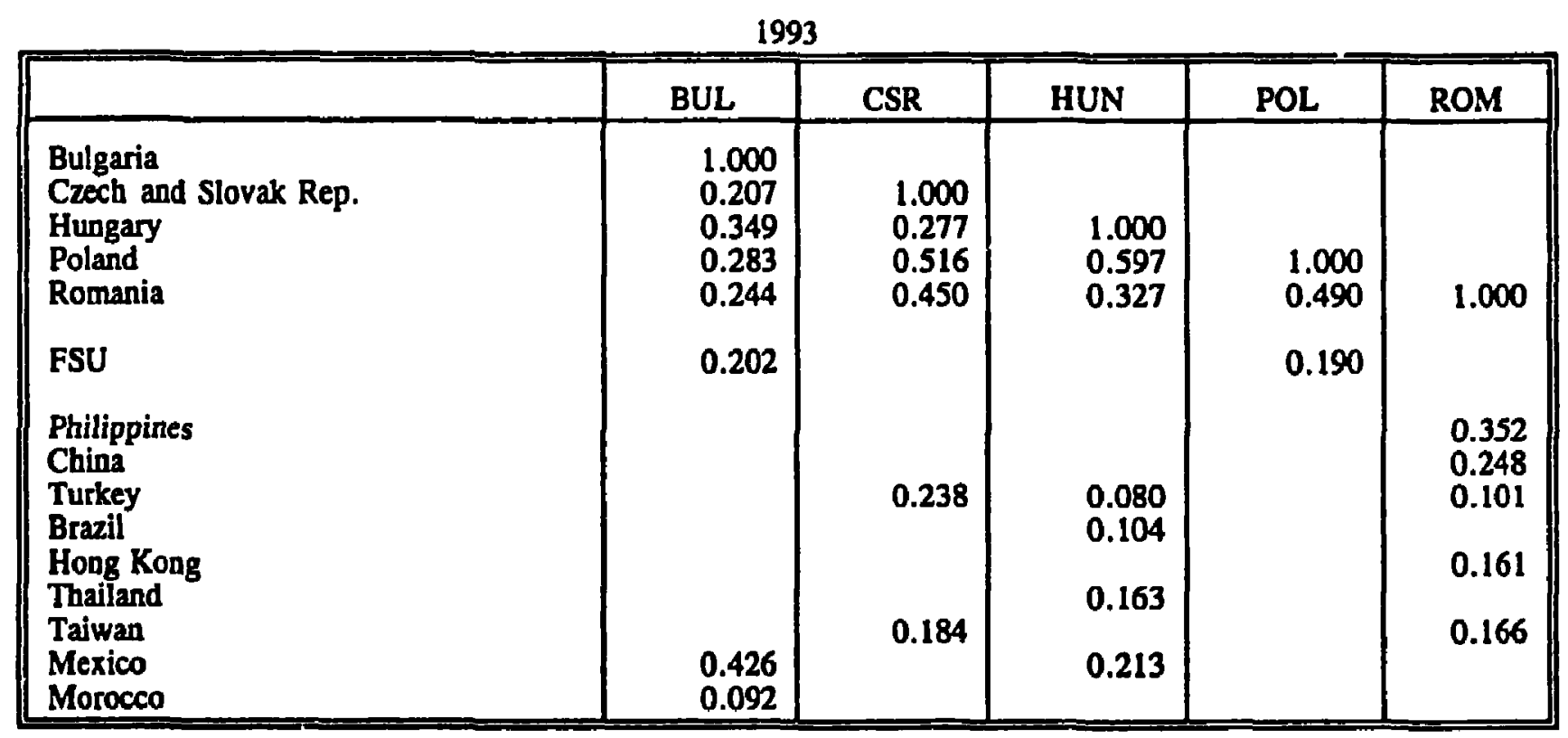

1989

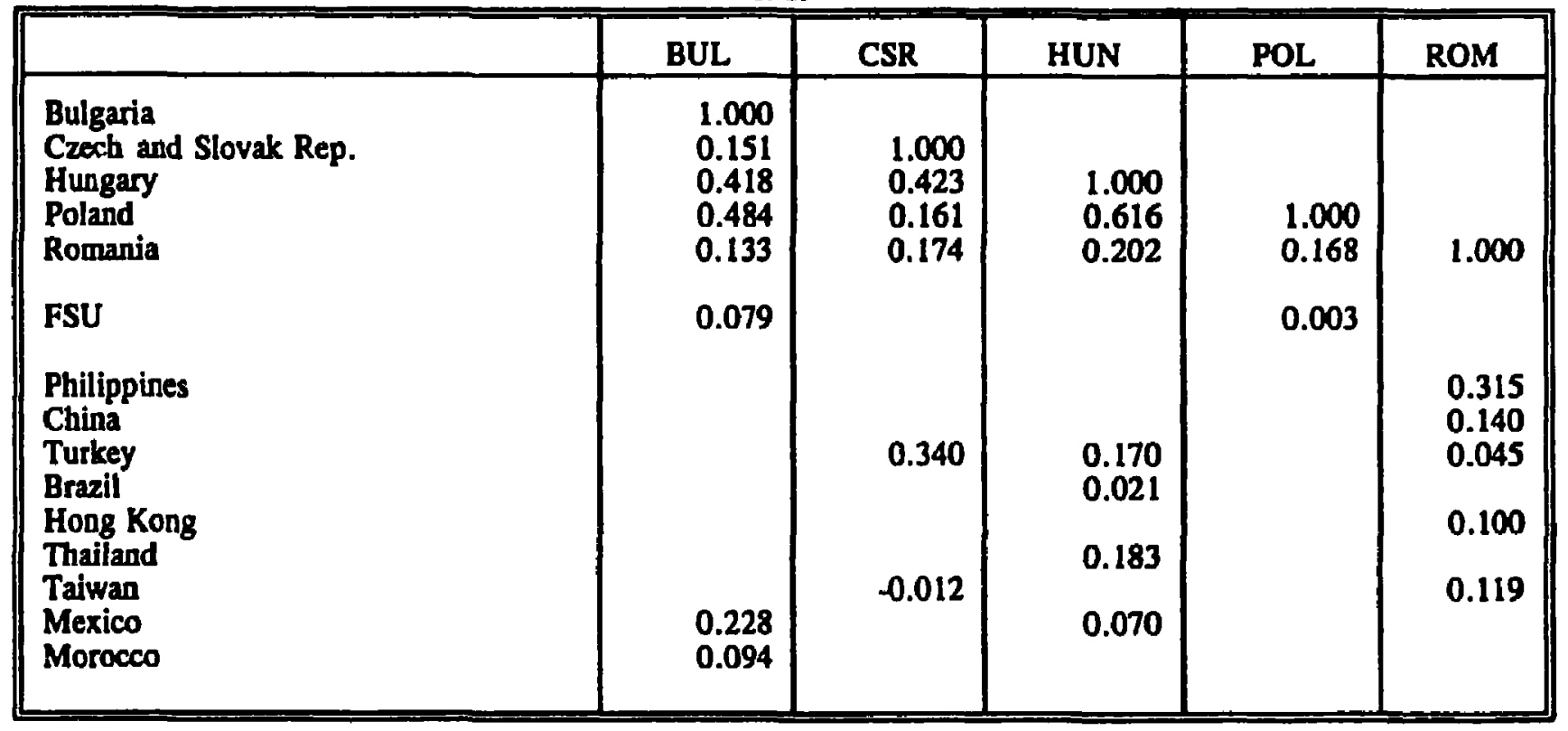




\section{Pollcy Research Working Paper Serles}

Title

WPS1411 Income Inequality, Welfare, and Poverty: An Illustration Using Ukrainian Data

WPS1412 Foreign Technology Imports and Economic Growth in Developing Countries

WPS1413 Endogenous Distortions in Product and Labor Markets

WPS1414 The World Bank and Legal Technical Assistance: Initial Lessons

WPS1415 China's GDP in U.S. Dollars Based on Purchasing Power Parity

WPS1416 informal Regulation of Industrial Pollution in Developing Countries: Evidence from Indonesia

WPS1417 Uncertainty and Global Waming: An Option-Pricing Approach to Policy

WPS1418 The Impact of Labor Market Regulations

WPS1419 Industry Structure and Regulation

WPS1420 Legislative Frameworks Used to Foster Petroleum Develspment

WPS1421 Distribution of licome and the Income Zeljko Bogetic Tax Burden in Bulgaria

Fareed M. A. Hassan

WPS1422 Efficiency in Bulgaria's Schools: A Nonparametric Study

WPS1423 The Role of Commercial Banks in Enterprise Restructuring in Central and Eastern Europe

WPS1424 Terms-of-Trade Shocks and Optimal Luis Serven Investment: Another Look at the Laursen-Metzler Effect

Xiaoming Zhang

Heng-lu Zou

Martin Rama

Guido Tabellini

The World Bank

Legal Department

Sethaput SuthiwartNarueput

William T. Onorato Sajal Chattophadyay

Millard Long Izabela Rutkowska
Contact

Date

tor paper

January 1995

C. Jones

3775t

January 1995

S. Fallon 38009

January 1995

K. Mathernova 82782

January 1995

E. O'Rielly-Campbell 33707

February 1995

E. Schaper 33457

February 1995 C. Dell 85148

February 1995

Martin C. Stewart-Smith

February 1995

N. James

82758

February 1995

W. Onorato 81611

February 1995

F. Smith 36072

February 1995

F. Smith

February 1995 36072

R. Gamer 37670

February 1995

E. Khine 37471 
Pollcy Research Working Paper Serles

\begin{tabular}{|c|c|c|c|c|}
\hline & Title & Author & Dale & $\begin{array}{l}\text { Contact } \\
\text { for paper }\end{array}$ \\
\hline WPS1425 & $\begin{array}{l}\text { On the Intersectoral Migration of } \\
\text { Agricultural Labor }\end{array}$ & $\begin{array}{l}\text { Donald Larson } \\
\text { Yair Mundlak }\end{array}$ & February 1995 & $\begin{array}{l}\text { J. Jacobson } \\
\mathbf{3 3 7 1 0}\end{array}$ \\
\hline WPS1426 & $\begin{array}{l}\text { Russian Unemployment: Its } \\
\text { Magnitude, Characteristics, and } \\
\text { Regional Dimensions }\end{array}$ & $\begin{array}{l}\text { Simon Commander } \\
\text { Ruslan Yemtsov }\end{array}$ & Fobruary 1995 & $\begin{array}{l}\text { V. Reid } \\
\mathbf{3 5 1 9 5}\end{array}$ \\
\hline WPS1427 & $\begin{array}{l}\text { Corporate Governance and Equity } \\
\text { Prices: Evidence from the Czech } \\
\text { and Slovak Republics }\end{array}$ & Stijn Claessens & February 1995 & $\begin{array}{l}\text { F. Hatab } \\
35835\end{array}$ \\
\hline WPS1428 & $\begin{array}{l}\text { Short-Term Supply Response to a } \\
\text { Devaluation: A Model's Implications } \\
\text { for Primary Commodity-Exporting } \\
\text { Developing Countries }\end{array}$ & $\begin{array}{l}\text { Bruno Boccara } \\
\text { Fabien Nsengiyumva }\end{array}$ & February 1995 & $\begin{array}{l}\text { M. Pfeiffenberger } \\
34963\end{array}$ \\
\hline WPS1429 & $\begin{array}{l}\text { The World Trade Organization's } \\
\text { Agreement on Government } \\
\text { Procurement: Expanding Disciplines, } \\
\text { Declining Membership? }\end{array}$ & $\begin{array}{l}\text { Bernard M. Hookman } \\
\text { Petros C. Mavroidis }\end{array}$ & March 1995 & $\begin{array}{l}\text { F. Hatab } \\
\mathbf{3 8 5 3 5}\end{array}$ \\
\hline WPS1430 & $\begin{array}{l}\text { Intergovernmental Fiscal Relations } \\
\text { and Poverty Alleviation in Viet Nam }\end{array}$ & $\begin{array}{l}\text { Richard M. Bird } \\
\text { Jennie I. Litvack } \\
\text { M. Govinda Rao }\end{array}$ & March 1995 & $\begin{array}{l}\text { G. Coward } \\
80494\end{array}$ \\
\hline WPS1431 & $\begin{array}{l}\text { The Industrial Pollution Projection } \\
\text { System }\end{array}$ & $\begin{array}{l}\text { Hemamala Heltige } \\
\text { Paul Martin } \\
\text { Manjula Singh } \\
\text { David Wheeler }\end{array}$ & March 1995 & $\begin{array}{l}\text { A. Williams } \\
37176\end{array}$ \\
\hline WPS1432 & $\begin{array}{l}\text { Using Financial Futures in Trading } \\
\text { and Risk Management }\end{array}$ & $\begin{array}{l}\text { Ignacio Mas } \\
\text { Jesús Saá-Requejo }\end{array}$ & March 1995 & $\begin{array}{l}\text { K. Binkley } \\
81143\end{array}$ \\
\hline WPS1433 & $\begin{array}{l}\text { Enterprise Restructuring in Eastem } \\
\text { Europe: How Much? How Fast? } \\
\text { Where? Preliminary Evidence from } \\
\text { Trade Data }\end{array}$ & $\begin{array}{l}\text { Bemard Hoekman } \\
\text { Gerhard Pohl }\end{array}$ & March 1995 & $\begin{array}{l}\text { F. Hatab } \\
35835\end{array}$ \\
\hline
\end{tabular}

